\title{
ASSESSMENT OF THE SOIL CONTAMINATION BY POTENTIALLY TOXIC ELEMENTS IN ALJUSTREL MINING AREA IN ORDER TO IMPLEMENT SOIL RECLAMATION STRATEGIES
}

\author{
C. Candeias ${ }^{1}$, E. Ferreira da Silva1, A.R. Salgueiro ${ }^{1,2}$; H.G. Pereira² ; J.X. Matos ${ }^{3}$; P.H. \\ Ávila ${ }^{1,4}$
}

${ }^{1}$ GeoBioTec - GeoBiosciences, Technologies and Engineering Research Center, Departamento de Geociências, Universidade de Aveiro, Campus de Santiago, 3810-193 Aveiro, Portugal

${ }^{2}$ CERENA - Natural Resources and Environment Research Center, Instituto Superior Técnico, Av. Rovisco Pais, 1049-001 Lisboa, Portugal

${ }^{3}$ Centro de Estudos Geológicos e Mineiros de Beja, Rua Frei Amador Arrais No. 39 r/c, Apartado 104, 7801-902 Beja, Portugal

${ }^{4}$ LNEG - National Laboratory of Energy and Geology, Lab. S. Mamede de Infesta, Rua da Amieira, Apartado 1089, 4466-901 S. Mamede de Infesta, Portugal (089, 4 466-901

(1)

Land pollution due to past mining activities is a major environmental issue in many European countries. The Aljustrel mine (SW Portugal) in the western sector of the Iberian Pyrite Belt. The visual and environmental impact of the mining activity in the region is a negative consequence conditioning the population life quality, result of the pyrite and sulphides exposed to air responsible for the pollution observed in soils, superficial water and stream sediments. This paper investigates the pollution load of potential toxic elements in soil samples collected around Aljustrel mining area, in order to assess the levels of soil contamination with respect to average concentrations of toxic elements in the region and to understand the partitioning and bioavailability of pollutants in the area.

The results showed severe soil contamination (mainly $\mathrm{As}, \mathrm{Cd}, \mathrm{Cu}, \mathrm{Pb}$ and $\mathrm{Zn}$ ). The concentrations of As (up to $3936 \mathrm{mg} \mathrm{kg}^{1}$ ) and certain heavy metals (up to $5414 \mathrm{mg} \mathrm{kg}{ }^{-} \mathrm{Cu}, 61.6 \mathrm{mg} \mathrm{kg}{ }^{-} \mathrm{Cd}, 20000$ $\mathrm{mg} \mathrm{kg}^{1} \mathrm{~Pb}$ and $20000 \mathrm{mg} \mathrm{kg}^{-} \mathrm{Zn}$ ) are two orders of magnitude above the South Portuguese background values. The median concentrations of $\mathrm{As}, \mathrm{Cd}, \mathrm{Cu}, \mathrm{Pb}$ and $\mathrm{Zn}$ exceed the values established for world soils, the European Union, Portugal and Andalusia. The results suggest that the distribution patterns of $\mathrm{Co}, \mathrm{Cr}$ and $\mathrm{Ni}$ element concentrations in the Aljustrel area are primarily influenced by the lithology and geochemistry nature of bedrock. The soil background of this geological domain is characterized by relatively high heavy metal contents, essentially derived from the parent rocks.

KeY words: Soil pollution; Potential Toxic Elements (PTE); Environmental geochemistry; Quality guidelines; Aljustrel mine; Iberian Pyrite Belt

\section{INTRODUCTION}

Although heavy metal mining can bring much needed economic prosperity, large areas of industrial wastelands often result once mining has ceased, with a legacy of abandoned tips and tailings, which contain the waste products of both mining and ore-processing operations (Santos Oliveira et al., 2002; Matos and Martins, 2006).

The disposal of mine wastes often produces more environmental problems than the mining operations themselves (Alvarenga et al., 2008). The piles of mine tailings (in general, fragmented and finely-ground materials) left in the vicinity, constitute one of the greatest threats, for the reason that their high concentration of heavy metals ( $\mathrm{As}, \mathrm{Cd}, \mathrm{Cu}, \mathrm{Hg}, \mathrm{Pb}, \mathrm{Zn}$ ) and toxic chemicals, environmentally sensitive locations, unstable nature, large number and often poor to non-existent maintenance. These materials when exposed to air and water, give rise to the oxidation of remaining sulphides, through chemical, electrochemical, and biological reactions, to form ferric hydroxides and sulphuric acid combined in acidic mine 
drainage (Cohen and Gorman 1991; Merson 1992; Evangelou and Zhang 1995; Larocque and Rasmussen 1998; Soucek et al. 2000).

As a direct result of the open-pit mining operations, soil is destroyed over a considerable area, and what is left of it is generally degraded and may continue causing environmental damage long after the mining period. Soil pollution with potentially toxic metals and metalloids represents one of the most prominent environmental hazards from abandoned mine lands (Thornton 1996). The soil fine fraction is usually enriched in metals, due to the relative large surface area of fine particles for adsorption and due to metal binding to iron and manganese oxides and to organic matter (Rasmussen 1998; Yukselen and Alpaslan 2001). Wind-blown dusts generated in those soils can be responsible for the atmospheric transport of trace metals (Rasmussen 1998). Therefore, soils are important sinks of heavy metals that could be inhaled, ingested, or absorbed, thereby entering the biosphere (Larocque and Rasmussen 1998). Heavy metals can persist in the soil over a long period and many of them are bioaccumulative or bio-magnified. This can result in long-term damage to flora and fauna and give rise to detrimental effects in humans, through introduction into the food chain and drinking water system.

Abandoned mines are one of the most serious environmental issues faced by many European countries and Portugal is not an exception (Pereira et al., 2004). These problems are particularly important within the mining areas where polymetallic sulphides were extracted.

In Portugal, pyrite extraction has a long tradition and represents an important industry which has given rise to several pollution problems, demanding urgent attention and remedial action (Fernandes and Henriques, 1989). Large volume of mine wastes occurs in the south of Portugal as a result of ore extracted from metalliferous mining works during the last 100 years. Approximately, $280 \mathrm{Mt}$ of massive polymetallic sulfides were extracted mainly for sulfur, from about 60 mines (Strauss and Madel, 1974).

An example is the Aljustrel mine, located in SW Portugal, in the western sector of the Iberian Pyrite Belt. The large-scale and intensive mining, mineral processing and smelting activities developed in the Aljustrel region, have left a legacy of huge quantities of waste rock piles, spoil heaps and tailing ponds that cause serious environmental damage. This study rises as a consequence of two research projects, e-Ecorisk - A regional Enterprise Network Decision Support System for Environmental Risk and Disaster Management of Large-Scale Industrial Spills (contract n. ${ }^{\circ}$ EV41-CT- 2002-00068) (European Project) and EVALUSE Environmental Vulnerability of Aljustrel Mining Area in Terms of Land Use (a project funded by the Portuguese government). The objectives of the present study were: (1) to determine total concentrations of As and metals of major concern in soils surrounding the Aljustrel mine site; (2) to evaluate the extent of pollution in soils impacted by local mining activities and by erosion of the tailings; (3) to discuss environmental implications arising from the metal pollution load on the basis of data on metal mobility (4) and to delineate guidelines regarding future clean-up operations in the affected area and monitoring purposes..

\section{THE STUDY AREA}

\section{Geographycal location and land use}

Aljustrel is located in Beja district, approximately $175 \mathrm{~km} \mathrm{SE}$ of Lisbon and $125 \mathrm{~km} \mathrm{~N}$ of Faro (Figure 1a). Aljustrel mine is one of the great lberian Pyrite Belt mining sites (Figure 1b), a world class volcanic hosted massive sulphides metalogenetic province (Barriga et al. 1997; Carvalho et al. 1999; Matos \& Martins 2006; Oliveira et al. 2006; Relvas et al. 2006; Tornos 2006).

The Aljustrel area is located in the hydrographical Roxo River basin, being the hydrographical network well developed. From west to east the most important local streams 
are: (a) Barranco do Farrôbo; (b) Água Azeda; (c) Água Forte.The Like any other part of southern Portugal, Mediterranean climate predominates in the region. The area is much warmer and receives less rainfall than the national average. The temperature reaches a maximum of $40^{\circ} \mathrm{C}$ in summer (i.e., July and August) and a minimum of $5^{\circ} \mathrm{C}$ in winter (i.e., December). The mean annual rainfall in the area is estimated to be $550 \mathrm{~mm}$, being the period from May to September very dry and wet from October to April (in average, 85 per cent of the total annual rainfall occurs during this period). The highest amount of rainfall occurs in December, while July and August are the driest months. The catchment is dominated by rolling plains and arable lands. According to FAO soil classification (FAO, 1999), soils of the study area were classified as Leptosols (occurring over a wide variety of parent rocks, mainly metasediments and acid volcanic-sedimentary materials), Luvisols (mainly associated to slates and greywackes) and Vertisols, Luvisols, Fluvisols and Cambisols associated to conglomerates and sandstones. Natural vegetation is mainly composed by Quercus rotundifolia, Cistus ladanifer, Genista hirsute, Cistus salviifolius, Cistus crispus, Cistus monspeliensis e Lavandula luisieri. In Aljustrel area the Quercus forests have been replaced by eucalyptus plantations (Eucalyptus camaldulensis).

\section{Geology and mineralization}

According to Schermerhorn \& Andrade (1971), Barriga (1990), Barriga \& Fyfe (1988), Barriga et al., (1997); Relvas et al. (1990), Dawson et al. (2001), Carvalho et al. (1999) among others, the geology of Aljustrel region is characterized by a Palaeozoic basement of the South Portuguese Zone and by a modern sedimentary sequence of the Alto Sado Tertiary Basin (USTB). The active NE-SW Messejana fault defines the SE border of this basin, which is confined to the NW block of the fault (Fig. 1c).

\section{Fig. 1}

The Messejana fault presents an Iberian dimension and a senestral strike-slip movement of $2.5 \mathrm{~km}$. This fault separates the Sado Tertiary Basin (NW side of the fault) of the Paleozoic (SE margin). Along this major structure a Jurassic dolerite (MD) is also observed (Schermerhorn et al. 1987).

According to several authors (Andrade \& Schermerhorn 1971; Schermerhorn and Stanton 1987; Silva et al. 1997; Leitão 1998; Matos 2005; Oliveira et al. 2006), the Aljustrel's Palaeozoic stratigraphic sequence is formed by the following main units: Baixo Alentejo Flysch Group (MFF): Mértola Formation (Upper Visean) - shales and greywackes (flysch turbidites). The Iberian Pyrite Belt: Volcano-Sedimentary Complex (VSC) (Upper Famennian - Upper Visean) represented by the following units: Paraíso Fm. - siliceous shales, phyllites, tuffites, purple shales, jaspers and cherts; felsitic/mine metavolcanics and green metavolcanics sequences - sericitic felsic volcanics, felsites, felsophyres, volcanic breccias, massive sulphides, feldspar megacryst volcanics and lavas. The IPB lower unit, the sedimentary Phyllite-Quartzite Group (Frasnian-Upper Famennian), is not recognized in the Aljustrel area. The VSC Aljustrel Anticlinorium is represented by a NW-SE lineament $(4.5 \mathrm{~km}$ length and $1.5 \mathrm{~km}$ across).

In the Aljustrel mining site, six massive sulphide orebodies are recognized along a $6 \mathrm{Km}$ structure of Vulcano-Sedimentary Complex: Moinho, Feitais, Estação, Gavião, Algares and São João, the last two were mined since Roman times (Silva et al. 1997; Leitão 1998; Matos \& Martins 2003, 2006). Moinho deposit was exploited by the Pirites Alentejanas Company (PA) for copper until 1993. The gossans and the supergene zones of the Algares and São João orebodies were exploited during roman era to $100 \mathrm{~m}$ deep (Domergue 1983). These massive sulphide orebodies have a simple mineralogy composed mainly by pyrite $\left(\mathrm{FeS}_{2}\right)(>$ $70 \%)$, with minor quantities of sphalerite $(\mathrm{ZnS})$, chalcopyirite $\left(\mathrm{CuFeS}_{2}\right)$, galena $(\mathrm{PbS})$, arsenopyrite (FeAsS), tetrahedrite $\left((\mathrm{Cu}, \mathrm{Fe})_{12} \mathrm{Sb}_{4} \mathrm{~S}_{13}\right)$ arsenopyrite (FeAsS), bornite $\left(\mathrm{Cu}_{5} \mathrm{FeS}_{4}\right)$, pirrotite $(\mathrm{Fe} 1-\mathrm{xS}(\mathrm{x}=0-0,17))$ e cassiterite $\left(\mathrm{SnO}_{2}\right)$ and sulfosalts (Matos \& Martins, 2006). The Mn mineralization is composed, essentially, by Mn oxides, namely pirolusite 
153

154

155

15.6

157

158

159

160

161

162

163

164

165

166

167

168

169

170

171

172

173

174

175

176

177

178

179

180

181

182

183

184

125

186

187

189

189

190

191

192

193

194

195

196

197

198

199

200

201

202

203

$\left[\mathrm{MnO}_{2}\right]$ and psilomelane $\left[\mathrm{MnO}_{2}\right]$, where is also possible to find limonite $\left[2 \mathrm{Fe}_{2} \mathrm{O}_{3} \cdot 3 \mathrm{H}_{2} \mathrm{O}\right]$, hematite $\left[\mathrm{Fe}_{2} \mathrm{O}_{3}\right]$ and baritine $\left[\mathrm{BaSO}_{4}\right]$.

\section{Mining activity and environmental impact in the Aljustrel area}

In result of thousands of years of intense pyrite ores exploitation in Aljustrel, large areas are now occupied by several waste tailings such as Roman slag, pyrite ore (blocks and brittle massive pyrite ore - the most reactive ones) and Volcano Sedimentary Complex host rocks. Algares industrial area and São João do Deserto sector present the highest volumes of mine waste. The total amount of waste stored on the site exceeds 3Mt (Matos \& Martins 2006). Those areas are affected by strong pluvial erosion, no vegetation and visible intense AMD. The small Mn-Fe exploitations are represented by small open pits and associated ore tailings, usually with less than $1 \mathrm{~m}$ thickness. Part of these small mines is used for illegal waste disposals. The environmental impact of these Mn-Fe exploitations is not quantified but is certainly locally significant. Other wastes are present in Aljustrel, with less contaminant potential like host rocks, represented by felsic well cleaved and coherent volcanics, siliceous, purple and black shales, jaspers and cherts (Volcano Sedimentary Complex host rocks). Roasted pyrite ore has a very low expression confined to spotty occurrences at Algares. Some of the mining infrastructures are unsafe and potentially dangerous, like open pits, quarries, galleries and mining shafts very exposed to local urban areas (Matos \& Martins 2006). The walls of São João do Deserto open pit and Malpique and Moinho quarries present significant geotechnical instability.

\section{MATERIALS AND METHODS}

\section{Field sampling and chemical analysis}

To investigate the impact caused by the dismantling and erosion of the tailings around the Aljustrel mine site, soil samples were collected in the area and analyzed. Soils were sampled on two occasions: the first sampling occurred during the summer of 2005 and encompassed soils from the VSC and MFF host rocks, and the second sampling occurred in the summer of 2006 and encompassed soils from the USTB. The studied area was monitored with a sampling network established on a $250-250 \mathrm{~m}$ grid in the centre of the contaminated area and 500-500 $\mathrm{m}$ in the remaining area (Figure 1c). Each sampling point was georeferenced by Global Positioning System (GPS). A total of 356 soil samples were collected over an area of $44 \mathrm{~km}^{2}$, corresponding to a sampling density of 8 samples $\mathrm{km}^{2}$. At each sampling point, the surface of the soil was cleared of superficial debris, vegetation and the O-soil horizont. A composite sample consisting of three subsamples was collected (with a minimum distance between subsamples of $3 \mathrm{~m}$ ) from the topsoil. According to the established grid the representativeness of the collected samples with the rock parent material is: $42.4 \%$ of samples is related with Tertiary Sado Basin Sediments (USTB); $1.7 \%$ with Messejana Dolerites (MD); 36.8\% with Baixo Alentejo Flysch group (MFF) and 19,1\% with VolcanoSedimentary Complex (VSC).After collection, the soil samples were dried in an oven at a temperature of $40^{\circ} \mathrm{C}$, until a constant weight was attained, disaggregated and passed through a 177, $\Perp \mathrm{m}$ aperture plastic sieve.

Surficial mine waste samples (upper $5 \mathrm{~cm}$ ) were sampled by collecting 10-increment composites. About $1 \mathrm{~kg}$ of each sample was crushed with a jaw crusher and pulverized in a mechanical agate mill. The samples were reduced to $250 \mathrm{~g}$ by coning and quartering, followed by drying at $40^{\circ} \mathrm{C}$. After homogenization aliquots of $30-50 \mathrm{~g}$ of each dried sample were powdered in a mechanical agate mill.

The fine grained fraction of soil and mine waste samples were submitted to multi-elemental analysis in an accredited Canadian laboratory (ACME Anal. ISO 9002 Accredited LabCanada). A $0.25 \mathrm{~g}$ split was leached in hot $\left(95^{\circ} \mathrm{C}\right)$ aqua regia $\left(\mathrm{HCl}-\mathrm{HNO}_{3}-\mathrm{H}_{2} \mathrm{O}\right)$ for 1 hour and diluted with $10 \mathrm{ml}$ of desmineralized water. Total concentrations (detection limits between brackets) of As $\left(0.5 \mathrm{mg} \mathrm{kg}^{-1}\right), \mathrm{Cd}\left(0.1 \mathrm{mg} \mathrm{kg}^{-1}\right), \mathrm{Co}\left(0.1 \mathrm{mg} \mathrm{kg}^{-1}\right), \mathrm{Cr}\left(1 \mathrm{mg} \mathrm{kg}^{-1}\right), \mathrm{Cu}(0.1 \mathrm{mg}$ 
204

205

206

207

208

209

210

211

212

213

214

215

216

217

218

219

220

221

222

223

224

225

226

227

228

229

230

231

232

233

234

235

236

237

239

239

240

241

242

243

244

245

246

247

248

249

250

251

252

253

$\left.\mathrm{kg}^{-1}\right)$, $\mathrm{Ni}\left(0.1 \mathrm{mg} \mathrm{kg}^{-1}\right)$, $\mathrm{Pb}\left(0.1 \mathrm{mg} \mathrm{kg}^{-1}\right)$ and $\mathrm{Zn}\left(1 \mathrm{mg} \mathrm{kg}^{-1}\right)$ were determined by Inductively Coupled Plasma-Emission Spectrometry (ICP-ES OPTIMA). The accuracy and analytical precision were determined using analyses of reference materials (standards C3 and G-2) and duplicate samples in each analytical set.

\section{Mineralogical studies}

Minerals of the tailings samples were determined by powder XRD using a Phillips powder diffractometer, model PW3040/601, equipped with an automatic slit. A Cu-X-ray tube was operated at $40 \mathrm{kV}$ and $30 \mathrm{~mA}$. Data were collected from 2 to $70^{\circ} 2 \mathrm{G}$ with a step size of $1^{\circ}$ and a counting interval of 0.6 seconds.

\section{Selective Chemical Extraction Procedure}

Chemical forms of heavy metals in soils directly influence their bioavailability and toxicity (Tessier et al. 1979; Ma \& Rao 1997; Zhou \& Sun 2002; Zhou et al. 2004).Trace metals can be transported in the secondary geological environment by different chemical mechanisms (Gibbs, 1973): a) in solution or adsorbed on solids, being readily available in these conditions; b) in organic compounds or metallic hydroxides, for which chemical changes are required before they are released; c) in the crystal structure of some minerals, where they are generally unavailable for the ecosystems.

Many schemes of sequential extraction to assess chemical speciation have been developed. In these schemes, samples are sequentially treated with different reagents in order that metals with different affinities for the mineral matrix can be liberated (Tessier et al., 1979; Meguellati et al., 1983; Rapin \& Forstner, 1983; Quevauviller et al., 1994; Gomez-Ariza et al., 2000).

A sequential chemical extraction procedure proposed by Cardoso Fonseca (1984) was adopted in this study. Reagents were applied sequentially to the solid phase of selected samples, according to their chemical aggressively. The extractable fractions of As, Cd, Co, $\mathrm{Cr}, \mathrm{Cu}, \mathrm{Fe}, \mathrm{Mn}, \mathrm{Ni}, \mathrm{Pb}$, and $\mathrm{Zn}$ were obtained by extraction with different solutions: (a) 1st Step - sodium acetate (NaOAc, $\mathrm{pH}$ 5) for extraction of exchangeable cations adsorbed by clay and co-precipitate by carbonates, to which are associate elements depending on $\mathrm{pH}$ for solving; (b) $2^{\text {nd }}$ Step - cold hydroxylamine for extracting amorphous Fe oxides and crystalline Mn oxides; (c) $3^{\text {rd }}$ Step - hot hydroxylamine for extraction of amorphous and crystalline Fe oxides and crystalline Mn oxides; (d) 4th Step - aqua regia, for extracting sulphides on clay minerals; (e) 5th Step - four acids digestion (or total attack) where the remaining silicate will be decomposed.

Selected samples for this SCE study were J6, K3, L5 and N5 (Figure 1c). This selection were based on the $\mathrm{As}, \mathrm{Cd}, \mathrm{Cr}, \mathrm{Cu}, \mathrm{Fe}, \mathrm{Mn}, \mathrm{Ni}, \mathrm{Pb}$ and $\mathrm{Zn}$ chemical analysis. The soil samples used in the SCE experiments were air-dried, disaggregated and sieved through a $177 \mathrm{~km}$ aperture plastic sieve. The fine grained $(<177 \mathrm{\mu m})$ fraction of soil samples was submitted to sequential chemical extraction procedure in ACTLABS accredited laboratory.

The accuracy of the sequential treatment, considered as a whole, was estimated by the comparison of the total sum of the amounts obtained after each sequential extraction step with the total amount obtained after hot mixed-acid attack of the same sample. For all the extractions, the total of the trace elements in the different fractions did not exceed $\pm 10 \%$ of the bulk sample which is accepted as satisfactory (Tessier et al, 1979; Pickering 1986; Yan et al, 1999).

\section{Data Analysis}

Statistical data analysis is a powerful tool in monitoring soil properties and assists in the interpretation of environmental data (Tuncer, 1993; Einax and Soldt, 1999). In recent times, statistical methods have been applied widely to investigate heavy metals concentration, accumulation and distribution in soils. This is documented by a large number of reported studies which apply statistical methods to heavy metals in soils. Salman et al. (1999), Yu-Pin 
254

255

256

257

258

259

260

261

262

263

264

265

266

267

268

269

270

271

272

273

274

275

276 $Z *\left(x_{0}\right) \quad \sum_{i=1}^{n} \lambda_{i} Z\left(x_{i}\right)$

277 where the $z_{-i}$ are weights found by solving the system of equations,

$$
\sum_{j}^{n} \lambda_{j} y\left(x_{i}, x_{j}\right)+\mu l \quad y\left(x_{i}, x\right), i=1, \ldots, n
$$

$$
\sum_{j}^{n} \lambda_{j}
$$

279 with $y(h)$ being the theoretical model for the variogram of the variable $Z$ (fitted to the sample 280 variograms) and $\mu$ being a Lagrange multiplier.

Contamination Factor and Modified Degree of Contamination: Hakanson (1980) proposed an overall indicator of contamination based on integrating data for a series of specific heavy metals. This method is based on the calculation for each pollutant of a contamination factor $\left(\mathrm{C}_{\mathrm{f}}\right)$. The $\mathrm{C}_{\mathrm{f}}$ is the ratio obtained by dividing the mean concentration of each metal in the soil $(\mathrm{Ci})$ by the baseline or background value of the specific metal $\left(\mathrm{C}_{\mathrm{b}}\right)$ Liu et al. (2005): $c_{F}=c_{i} / c_{b}$

$\mathrm{C}_{\mathrm{f}}=\mathrm{C}_{\mathrm{i}} / \mathrm{C}_{\mathrm{b}}$

$\mathrm{C}_{\mathrm{f}}$ is defined according to four categories as follows (Liu et al. 2005):

$\mathrm{C}_{\mathrm{f}}<1$ - low concentration factor

$1<\mathrm{C}_{\mathrm{f}}<3$ - moderate contamination factor

$3<\mathrm{C}_{\mathrm{f}}<6$ - considerable contamination factor 
292

293

294

295

296

297

298

299

300

301

302

303

304

305

306

307

308 309

310

311

312

313

314

315

315

317

318

319

320

321

322

323

324

325

326

327

328

329

330

331

332

333

334

335

336

337 339

\section{$\mathrm{C}_{\mathrm{f}}>6$ - very high contamination factor}

Abrahim (2005) presented a modified and generalized form of the Hakanson (1980) equation for the calculation of the overall degree of contamination as below.

$m c_{f}=\left(\sum_{i=1}^{r=n} c_{f}\right) / n$

where:

$\mathrm{n}=$ number of analyzed elements and $\mathrm{i}=\mathrm{ith}$ element (or pollutant) and $\mathrm{C}=$ Contamination factor.

For the classification and description of the modified degree of contamination $\left(\mathrm{mC}_{\mathrm{f}}\right)$ in soil the following gradations are proposed by Abrahim and Parker (2008):

$\mathrm{mC}_{\mathrm{f}}<1.5-$ Nil to very low degree of contamination

$1.5<\mathrm{mC}_{\mathrm{f}}<2$ - Low degree of contamination

$2<\mathrm{mC}_{\mathrm{f}}<4$ - Moderate degree of contamination

$4<\mathrm{mC}_{\mathrm{f}}<8$ - High degree of contamination

$8<\mathrm{mC}_{\mathrm{f}}<16$ - Very high degree of contamination

$16<\mathrm{mC}_{\mathrm{f}}<32$ - Extremely high degree of contamination

$\mathrm{mC}_{\mathrm{f}}>32$ - Ultra high degree of contamination

\section{RESULTS}

\section{Distribution of PTE in topsoil}

A global dataset composed by 356 soil samples and 10 variables (As, Cd, Co, Cr, Cu, Fe, $\mathrm{Mn}, \mathrm{Ni}, \mathrm{Pb}$ and $\mathrm{Zn}$ concentrations) was assembled. A descriptive statistical analysis permit to describe and resume a set of data that allows finding the anomalous structures presents. Descriptive statistical parameters for trace elements for global data and categorized according to the parent rock lithology are summarized in Table 1. These values were compared with $\mathrm{As}, \mathrm{Cd}, \mathrm{Co}, \mathrm{Cr}, \mathrm{Cu}, \mathrm{Ni}, \mathrm{Pb}$ and $\mathrm{Zn}$ reference median values reported in worldwide soils (Global soil mean - Reimann and De Caritat, 1998), European Union (Levinson, 1980), South Portuguese zone and Andalusia )Galán et al., 2002, 2008) listed in Table 2. In this study, the concentration of potentially hazardous trace elements and extent of pollution load have been quantified and related to soil quality guide values such as the Portuguese (Ferreira, 2004), Andaluzia (Galán et al., 2002, 2008) and Netherlands (Alloway, 1995).

The total As content in soil samples from Aljustrel area varies between $6 \mathrm{mg} \mathrm{kg}^{-1}$ and 3936 $\mathrm{mg} \mathrm{kg}^{-1}$, with a median value $\left(18 \mathrm{mg} \mathrm{kg}^{-1}\right)$ similar to the topsoil baseline for As in the SPZ (21 $\left.\mathrm{mg} \mathrm{kg}^{-1}\right)$. However the median values are quite different depending on the location of the samples with respect to parent rock material (Table 1). The samples collected in the VSC units are clearly the most enriched soils exceeding in some cases 14.5 times the SPZ baseline. These values clearly exceed the median As concentrations for soils of the world (5 $\left.\mathrm{mg} \mathrm{kg}^{-1}\right)$, the European Union $\left(7 \mathrm{mg} \mathrm{kg}^{-1}\right)$, and the baseline values for Portugal and also the Andalusia region $\left(10 \mathrm{mg} \mathrm{kg}^{-1}\right)$. The As threshold value of the SPZ $\left(179 \mathrm{mg} \mathrm{kg}^{-1}\right)$ is also exceeded in soils collected in the VSC and MFF geological units (circa $8 \%$ of soil samples exceeded the threshold value). The distribution of high values is related to sulphide ore occurrence and mining activities. Some samples collected in the vicinity of Algares and S. João do Deserto are in the range of values above which toxicity is considered to be possible (Kabata-Pendias and Pendias, 1992).

The total Cd content in the Aljustrel soil samples ranges from 0.1 to $61.6 \mathrm{mg} \mathrm{kg}^{-1}$, with $0.2 \mathrm{mg}$ $\mathrm{kg}^{-1}$ as a median value. This median value is lower than the one for world soils $\left(1 \mathrm{mg} \mathrm{kg}^{-1}\right)$ 
the European Union soils $\left(0.3 \mathrm{mg} \mathrm{kg}^{-1}\right)$ and Portuguese soils $\left(<0.2 \mathrm{mg} \mathrm{kg}^{-1}\right)$. Locally, some soils remain enriched in $\mathrm{Cd}$ (concentrations ranging from 1.0 to $61.6 \mathrm{mg} \mathrm{kg}^{-1}$ ) representing $4.5 \%$ of the total samples. These extreme values are registered in soils related to the VSC, MD and MFF geological units.

In the Aljustrel area, the median for Co $\left(16 \mathrm{mg} \mathrm{kg}^{-1}\right)$ are similar to the corresponding values in the SPZ (19.0 mg kg-1) while the threshold value in the SPZ is $36 \mathrm{mg} \mathrm{kg}^{-1}$. The extreme values observed in the VSC and MFF units may have a geologic origin because they apply to soils developed on shales and greywackes (flysch turbidites), phyllites, tuffites, purple shales, jaspers and cherts, sericitic felsic volcanics, felsites, felsophyres, volcanic breccias, massive sulphides, feldspar megacryst volcanics and lavas with high Co contents The high Co concentrations in soil may also be due to adsorption and coprecipitation involving $\mathrm{Fe}$ and/or Mn from parent rocks rich in these metals or from mineralisation (Salminen and Tarvainen, 1997). The median values for Co observed in the Aljustrel area are similar for all the soil derived from the different parent-rocks categories $\left(16 \mathrm{mg} \mathrm{kg}^{-1}\right)$, however this value is also higher than that for the world soils $\left(10 \mathrm{mg} \mathrm{kg}^{-1}\right)$ the European Union soils $\left(8 \mathrm{mg} \mathrm{kg}^{-1}\right)$ and the baselines of Portuguese $\left(8 \mathrm{mg} \mathrm{kg}^{-1}\right)$ and Andalusia soils $\left(12 \mathrm{mg} \mathrm{kg}^{-1}\right)$.

The total $\mathrm{Cr}$ content in soil samples from Aljustrel area varies between $6 \mathrm{mg} \mathrm{kg}^{-1}$ and $115 \mathrm{mg}$ $\mathrm{kg}^{-1}$, with a median value $\left(56 \mathrm{mg} \mathrm{kg}^{-1}\right)$. The median values observed in soil samples derived from the different parent-rocks categories are below the SPZ threshold value $\left(248 \mathrm{mg} \mathrm{kg}^{-1}\right)$. The outlier values are related to basic intrusive and volcanic rocks, and other $\mathrm{Cr}$-rich parent rocks, such as metabasites. Based on this geochemical relationship between $\mathrm{Cr}$ content in topsoil and specific lithology of the bedrock, it is likely that the Cr outliers have a geologic origin.

The total $\mathrm{Cu}$ concentration ranges between 10 to $5414 \mathrm{mg} \mathrm{kg}^{-1}$, with a median of $39 \mathrm{mg} \mathrm{kg}^{-}$ (the median value of $\mathrm{Cu}$ in topsoil is $32 \mathrm{mg} \mathrm{kg}^{-1}$ in the SPZ, Galán et al., 2008). The baseline levels in the Aljustrel are also above the median of the $\mathrm{Cu}$ concentrations in soils of the world $\left(25 \mathrm{mg} \mathrm{kg}^{-1}\right)$, the European Union $\left(13 \mathrm{mg} \mathrm{kg}^{-1}\right)$ and Andalusia region $\left(24 \mathrm{mg} \mathrm{kg}^{-1}\right)$. In the Aljustrel area the high $\mathrm{Cu}$ contents of topsoil appear to be associated with acid volcanosedimentary rocks (VSC). The Cu content of anomalous samples of VSC surpasses the threshold values of the SPZ for topsoil (147 mg kg-1 - Galán et al., 2008) indicating a probable relation with regional and local mineralization and with the mining wastes (some samples show a topsoil/parent rock ratio ranging from 10 to 140).

The total Ni content in soil samples from Aljustrel area varies between $2 \mathrm{mg} \mathrm{kg}^{-1}$ and $106 \mathrm{mg}$ $\mathrm{kg}^{-1}$, with a median value $\left(30 \mathrm{mg} \mathrm{kg}^{-1}\right)$. The median value obtained for the Aljustrel database is very similar to the baseline levels for $\mathrm{Ni}$ in the SPZ $\left(37 \mathrm{mg} \mathrm{kg}^{-}\right)$and are well above those for soils of the world $\left(20 \mathrm{mg} \mathrm{kg}^{-1}\right)$ and the European Union $\left(18 \mathrm{mg} \mathrm{kg}^{-1}\right)$, and slightly exceed the regional "background" value for the Portuguese and Andalusia soils (16 and $29 \mathrm{mg} \mathrm{kg}^{-1}$, respectively). All the values, except for soil samples derived from the MFF geological unit do not exceed the threshold values for $\mathrm{Ni}$ in the SPZ $\left(63 \mathrm{mg} \mathrm{kg}^{-1}\right)$. The anomalous MFF samples derived from shales and greywackes (flysch turbidites). In most of these sampling sites, the topsoil/parent rock ratio is low, indicative of a lithological origin.

The median $\mathrm{Pb}$ content in the Aljustrel area is about $38 \mathrm{mg} \mathrm{kg}^{-1}$, although some extreme values (up to $20000 \mathrm{mg} \mathrm{kg}^{-1}$ ) were recorded. The study area records exceed the threshold value for Pb in the SPZ (205 $\left.\mathrm{mg} \mathrm{kg}^{--}\right)$in the VSC, MD and MFF related soil samples $(11 \%$ of soil samples surpass the threshold value). The median values obtained in these areas exceed the "backgrounds" estimated for soils of the world $\left(70 \mathrm{mg} \mathrm{kg}^{-1}\right)$, the European Union $\left(52 \mathrm{mg} \mathrm{kg}^{-1}\right)$ and the Portuguese and Andalusia soils (21 and $56 \mathrm{mg} \mathrm{kg-1}$, respectively;. The extreme values are given in topsoil samples from the VSC and MFF geological units. These soils samples derived from acid volcano-sedimentary materials of the Iberian Pyrite Belt. The maximum $\mathrm{Pb}$ concentration $\left(20000 \mathrm{mg} \mathrm{kg}^{-1}\right)$ observed in these samples show a topsoil/parent rock ratio ranging from 10 to 526 indicating contamination from mining operations. 
391

The total $\mathrm{Zn}$ content in the Aljustrel soil samples ranges between 22 and $20000 \mathrm{mg} \mathrm{kg}^{-1}$ with an median value of $88 \mathrm{mg} \mathrm{kg-1}$, which is slightly above the baseline concentration in the SPZ (76 $\mathrm{mg} \mathrm{kg}^{-1}$ ). The median value obtained for the Aljustrel soils exceed the median $\mathrm{Zn}$ concentrations in world soils $\left(70 \mathrm{mg} \mathrm{kg}^{-1}\right)$, the European Union (52 $\mathrm{mg} \mathrm{kg}^{-1}$ ) and the Portuguese and Andalusia soils (55 and $56 \mathrm{mg} \mathrm{kg}^{-1}$, respectively). The threshold value for $\mathrm{Zn}$ in the in the SPZ (173 $\mathrm{mg} \mathrm{kg}^{-1}$ ) is exceed in $17 \%$ of samples. The extreme $\mathrm{Zn}$ concentrations (up to $20000 \mathrm{mg} \mathrm{kg}^{-1}$ ) occur at the top of the soils from parent materials belonging to the volcano-sedimentary complex of the Iberian Pyrite Belt. The topsoil/parent material ratio varies widely between 3.6 and 9.4 in the $\mathrm{OMZ}$, and from 0.2 to 263. The origin of this $\mathrm{Zn}$ enrichment seems to result from sulphide mineralization and anthropogenic pollution due to mining activities.

\section{Partitioning of metals in selected samples}

Determining the total concentrations provides insight about the extent of metal accumulation and the pollution load, but does not properly describe the environmental risk of the potentially contaminated soils since not all the metals present in the soil are biologically available ( $\mathrm{Li}$ and Thornton 2001). Four samples (K3, N5, L5 and J6 - see figure 1c) were selected for the sequential leaching of heavy metals according to the results obtained.

The XRD results show that the mineralogy of the different selected soil samples is very similar. Soil samples are commonly composed of quartz $\left(\mathrm{SiO}_{2}\right)$, plagioclase $(\mathrm{Na}, \mathrm{Ca})(\mathrm{Si}, \mathrm{Al})_{4} \mathrm{O}_{8}$, phylosilicates $\left(\mathrm{Al}_{2} \mathrm{Si}_{2} \mathrm{O}_{5}(\mathrm{OH})_{4}\right)$. The soil samples are characterized, in most cases, by the presence of remarkable amounts of iron oxy-hydroxides [goethite $(\mathrm{FeOOH})$, hematite $\left(\mathrm{Fe}_{2} \mathrm{O}_{3}\right)$, magnetite-maghmite $\left(\mathrm{Fe}_{3} \mathrm{O}_{4}-\left(\mathrm{Fe}_{2} \mathrm{O}_{3}\right)\right]$ and sulfates, mainly jarosite ( $\mathrm{KFe}^{(\mathrm{III})}$ $\left.(\mathrm{OH})_{6}\left(\mathrm{SO}_{4}\right)_{2}\right)$, alunite $\left(\mathrm{KAl}_{3}\left(\mathrm{SO}_{4}\right)_{2}(\mathrm{OH})_{6}\right)$, anidrite $\left(\mathrm{CaSO}_{4}\right)$, gypsum $\left(\mathrm{CaSO}_{4} 2 \mathrm{H}_{2} \mathrm{O}\right)$ and thernardite $\mathrm{Na}_{2} \mathrm{SO}_{4}$ ], derived from an active sulfuricization process. Iron oxy-hydroxides usually occur as extremely fine grained, poorly crystalline aggregates and coatings. The soils still can contain some crystals of reactive sulfide such as pyrite, arsenopyrite and galena. Punctually some siderite $\left(\mathrm{FeCO}_{3}\right)$ and plumbogummite $\left(\mathrm{PbAl}_{3}\left(\mathrm{PO}_{4}\right)_{2}(\mathrm{OH})_{5} \cdot\left(\mathrm{H}_{2} \mathrm{O}\right)\right)$ occur in the studied samples. The clay mineral assemblage identified by XRD is dominated by kaolinite, with minor poorly defined mixed-layer minerals.

The affinity of metal concentrations in five geochemical fractions (metal bearing-phases) is presented in Figure 2. The results show that the most important As bearing-phases, for the four selected samples are the sulphides and clay minerals (arsenic was extracted mainly by aqua regia, with the percentage of extraction ranging between $82 \%$ to $93 \%$ - samples N5, $\mathrm{K} 3, \mathrm{~L} 5$, in ascending order of percentage of extraction). Some As is also linked to the Fe crystalline oxides (N5 -13\% and $\mathrm{J} 6-5 \%$ ). It should be noted, taking into account the results of the mineralogical study of samples, that As may be associated with the presence of arsenopyrite and may also be associated with magnetite and iron pyrite. Moreover the percentage of extraction with sodium acetate, $\mathrm{pH} 5.0$ (extraction of exchangeable cations and clay items added by the co-precipitated as carbonates) in the studied samples are very low in most samples, but sample N5 show a value of $0.32 \%$ of extraction. These results can become very important, because the As concentrations associated with this percentages of extraction (4.5 $\mathrm{mg} \mathrm{kg}^{-1}$ ) are high, accounting for a significant amount of As in bioavailable form. According to Reiman \& Caritat (1998), values greater than $0.06 \mathrm{mg} \mathrm{L}^{-1}$ in water requires remediation of contaminated site.

Cadmium (Figure 2) also shows, as major bearing-phases, sulphides and clay minerals (with percentage of extraction of aqua regia to vary between 20.6 and $55.9 \%$ - most representative in samples K3, L5, J6,) and remaining silicates (the percentage of extraction vary between 17.3 and $28.0 \%$ - most representative in samples $\mathrm{K} 3$ and $\mathrm{J} 6$ to total attack). It is worth nothing that in some sample a significant percentage is linked to exchangeable cations/adsorbed and Fe/Mn amorphous and crystalline oxides. Taking into account the results one can say that the presence of $\mathrm{Cd}$ is justified by the occurrence of sphalerite in the soil samples. Sphalerite was not been identified by XRD because mineralogical 
characterization by XRD does not allow the detection of mineral phases present in small proportions, which could be a point of interest since $\mathrm{Cd}$ usually replaces $\mathrm{Zn}$ in the crystalline network of the sphalerite. Among these results should be highlighted the percentage of extraction with sodium acetate $(\mathrm{pH} 5.0)$ obtained in all samples, meaning that a significant amount of $\mathrm{Cd}$ is associated to exchangeable cations or adsorbed, representing its readily available forms of $\mathrm{Cd}$. According to the results it concentrations of $\mathrm{Cd}$ readily available may vary from 0.48 to $0.69 \mathrm{mg} \mathrm{kg}^{-1}$. According Reiman \& Caritat (1998) values of $\mathrm{Cd}$ concentration over $0.004 \mathrm{mg} \mathrm{L}^{-1}$ in water samples require remediation.

For Co (Figure 2), the results show clearly the dominance of silicate minerals as metal bearing-phases (the \% of extraction ranges between 50.4 and $80.7 \%$ ). The results are in agreement with the VMS geological context.

Chromium results show that a large proportion of this element is associated with silicate minerals (the \% of extraction ranges between 50.4 and $80.7 \%$ ). The results are in agreement with the geological context. It is recalled that the parent rock lithology of samples K3, N5, L5 and $\mathrm{J} 6$ is the Paraiso Formation, represented by siliceous shales, phyllites, tuffites, purple shales, jaspers and cherts; felsitic/mine metavolcanics and green metavolcanics sequences - sericitic felsic volcanics, felsites, felsophyres, volcanic breccias, massive sulphides, feldspar megacryst volcanics and lavas. Most of the $\mathrm{Cr}$ concentrations in the selected samples are very low.

The SCE results shows that Cu sulphides and clay minerals (with percentage of extraction of aqua regia (Step 4) varying between 43.2 and 65\% - samples K3 and L5, respectively) and silicates (percentage of extraction, the total attack (Step 5), vary between $5.7 \%$ and $22.2 \%$ $\mathrm{J} 6$ and N5, respectively), as the most important bearing-phases of $\mathrm{Cu}$. However it appears that the percentages of extraction cold hydroxylamine are also significant (percentage of extraction ranging between 18.9 and $27.9 \%$ ) demonstrating an important contribution of amorphous iron oxides and manganese oxides. Punctually $\mathrm{Fe} / \mathrm{Mn}$ crystalline oxides represent also an important $\mathrm{Cu}$ metal bearing-phase (17\% of extraction in sample $\mathrm{J} 6$ by hot hydroxylamine). Similarly to sphalerite, chalcopyrite was not identified by XRD analysis. The percentage of extraction with sodium acetate $(\mathrm{pH} 5.0)$ obtained in all samples (values ranging between 0.6 to $13.8 \%$ indicates that an important amount of $\mathrm{Cu}\left(0.9\right.$ to $\left.170 \mathrm{mg} \mathrm{kg}^{-1}\right)$ could be easily available.

Figure 2 show that $\mathrm{Ni}$ is preferably linked with sulphides and clay minerals (percentage of extraction, the aqua regia, varying between 43 and $76.3 \%-\mathrm{J} 6$ and $\mathrm{L} 5$, respectively) and also with remaining silicate minerals (with a percentage of extraction, ranging between 7.9 and $51.4 \%$ - L5 and J6, respectively). The total Ni concentrations in the selected samples is very low $\left(4-11 \mathrm{mg} \mathrm{kg}^{-1}\right)$ but it should be noted that the percentage values obtained for sodium acetate extraction are relatively high in some samples $(11.3 \%-\mathrm{L} 5 ; 12.9 \%-\mathrm{N} 5 ; 27.7 \%-\mathrm{K} 3)$, meaning that $\mathrm{Ni}$ could be associated to the interchangeable fraction and be easily mobilized.

Lead concentrations are extremely high (values ranging between 2020 and $20000 \mathrm{mg} \mathrm{kg}^{-1}$ ) in the selected samples. According to the results $\mathrm{Pb}$ appears associated to sulphides (34 to 84 $\%$ of extraction associated with Step 4), but also it is associated with the remaining silicates (14 to $45 \%$ of extraction associated with Step 5). The results indicate that, for most samples, the presence of galena $(\mathrm{PbS})$ is responsible for high $\mathrm{Pb}$ concentration in soil samples, since the percentage of lead extracted by aqua regia is important. It appears that the residual values of silicate shows high percentage of extraction. Should not be put aside the importance of hydroxides of $\mathrm{Pb}$, represented in the sample $\mathrm{K} 3$ by plumbogummite $\left(\mathrm{PbAl}_{3}\left(\mathrm{PO}_{4}\right)_{2}(\mathrm{OH})_{5} .\left(\mathrm{H}_{2} \mathrm{O}\right)\right)$. In addition, the results evidence that in some samples $\mathrm{Pb}$ may be also interchangeable (2.8 to $6.1 \%$ ).

Like $\mathrm{Pb}, \mathrm{Zn}$ concentration is also very high (levels ranging between 422 and $2378 \mathrm{mg} \mathrm{kg}^{-1}$ ). Zinc was found essentially associated to $\mathrm{Zn}$ sulphides and clay minerals (percentage of extraction, the aqua regia, ranging between 65 and $72 \%$ - samples $\mathrm{J} 6$ and N5, respectively). 
494

495

496

497

498

499

500

501

502

503

504

505

506

507

508

509

510

511

512

513

514

515

516

517

518

519

520

521

522

523

524

525

526

527

528

529

530

531

532

533

534

535

536

It can be noted that a significant proportion of zinc is associated with amorphous Fe oxides (7.2 to $23.6 \%$ of extraction - N5 and K3 respectively).

The values of percentage of extraction obtained for the sodium acetate, (ranging between 3.4 and $42 \%$ - L5, K3) justify emphasis. Considering the high total $\mathrm{Zn}$ concentrations, the values of available $\mathrm{Zn}$ (such as 174 and $265 \mathrm{mg} \mathrm{kg}^{-1}$ in samples K3 and N5), can be easily mobilized to the water surface and interfere with the local runoff. As one would expect the images obtained for the $\mathrm{Zn}$ and $\mathrm{Cd}$ are similar, which indicates a strong correlation between these two elements since they are associated with the same metal bearing-phase (sphalerite).

Iron, as expected due to the sample mineralogical composition, is basically found distributed in two fraction: sulphides (main fraction - in average $88 \%$ of extraction) and also with iron and manganese oxides (3.8 to $9.8 \%$ of extraction - see Figure 2). This distribution is very similar to that obtained for As. Manganese is associated with the sulphides/clay minerals and with the remaining silicates fraction. It is also found an important proportion in the fraction associated with the interchangeable/adsorbed/co-precipitated of carbonates fraction (24.6 to $40.9 \%$ of extraction). The presence of jarosite in topsoils creates an additional contamination problem since jarosite-type phases act as temporary storage for acidity and may release this stored acidity upon hydrolysis and redissolution (Miller, 1995).

The partitioning data obtained shows that most of the elements were mainly associated with the sulphides/clay minerals and the residual fraction of the soil (for $\mathrm{As}, \mathrm{Cu}$ and $\mathrm{Pb}$, more than $70 \%$ of the total metal content was in the residual fraction). The metal extracted by the first step was less than $5 \%$ of the total content for $\mathrm{As}, \mathrm{Cu}$ and $\mathrm{Pb}$. The exception was $\mathrm{Cd}$ and $\mathrm{Zn}$ were the metal extracted by the first step ranged between 10 and $40 \%$. The fraction extracted by the first step is according Kennedy et al. (1997) considered a relative empirical estimate of metal bioavailability.

\section{Environmental quality and remediation actions}

In this study, a simplified approach to risk assessment based on comparing the measured level of contamination in the Aljustrel soils with local median values (Table 1) were adopted. Table 3 shows the results of contamination factors considering the global data and the data categorized according to the parent rock lithology.

The results reveal that globally the Aljustrel area presents a moderate degree of heavy metal contamination. According to the results the contamination factor for $\mathrm{As}$ and $\mathrm{Pb}$ are considerable and moderate for $\mathrm{Cd}, \mathrm{Cu}$ and $\mathrm{Zn}$. The highest $\mathrm{C}_{\mathrm{f}}$ is observed for $\mathrm{Pb}$ which is significant in soils from the VSF and MFF geological units. The soil samples from the MD geological unit reveal noticeably contamination in $\mathrm{Zn}$ and $\mathrm{Cd}$. Revised Hakanson equation was used to calculate the modified degree of contamination $\left(\mathrm{mC}_{\mathrm{f}}\right)$ for the eight analyzed elements (Table 3). The range of $\mathrm{mC}_{\mathrm{f}}$ values (1.10-12.3) indicates a low to moderate degree of contamination in the Aljustrel area being particularly higher in soils from the VSC and MFF geological units. According to the results the USTB soils are considered as not contaminated or with low contamination. According to the contamination factors values among the eight metals tested, As, Cd, Cu, $\mathrm{Pb}$ and $\mathrm{Zn}$ were the elements of most concern whereas $\mathrm{Co} \mathrm{Cr}$ and $\mathrm{Ni}$ show values near 1 meaning that were not significantly pollution occur in the area.

Soil quality for environmental purposes can be measured in many different ways (e.g. Pierzynski et al., 1994; Sims et al., 1997; Galán et al., 2002). In this work the Andalusia (Galán et al, 2002) and the Portuguese (Ferreira, 2004) quality standards were adopted for comparison and to establish recommendations for soil management. Figure 3 to 7 presents maps of $\mathrm{As}, \mathrm{Cd}, \mathrm{Cu}, \mathrm{Pb}$ and $\mathrm{Zn}$ spatial distribution, according to the soil management guidelines. Table 4 presents the sample distribution between the different classes taking in consideration the Andaluzia Guide Values.

The pattern presented by $\mathrm{As}, \mathrm{Cu}, \mathrm{Pb}, \mathrm{Zn}$ suggest that the area surrounding the Algares $(\mathrm{A})$ and S. João do Deserto (b) mines needs intervention. According to the Andalusia guide 
values there were $17.1 \%, 5.3 \%, 6.7 \%$ and $1.7 \%$ of soil samples that fall in the Class 4 (intervention is needed) because they are polluted by $\mathrm{As}, \mathrm{Cu}, \mathrm{Pb}$ and $\mathrm{Zn}$, respectively (Table 4). Among the five metals, As and $\mathrm{Pb}$ ranked the first two polluted elements in term of the extent of contamination. According to the Portuguese guide values there were $18.0 \%, 46.6 \%$, $19.4 \%$ and $46.6 \%$ of soil samples that fall in the Class 4 (intervention is needed). The differences obtained for the $\mathrm{Cu}, \mathrm{Pb}$ and $\mathrm{Zn}$ variables are explained by the enrichment of the local geological formations in these elements.

These results are of most importance since an exchangeable fraction of $\mathrm{As}$ and $\mathrm{Pb}$ were detectable in some soil samples, as noted in the selective chemical extractio. Also, from Cd pattern is possible to conclude that punctual $\mathrm{Cd}$ contamination occurs in the S. João do Deserto area based on the assessment method. According to Glanzman \& Closs (1993), Cd is considered a priority pollutant metal, meaning that is of great interests for environmental impact studies.

As noted above, the soils close to the mining areas retain anomalously high concentrations of a cocktail of potentially toxic elements rather than only one pollutant. Considering the $A$ and $B$ areas individually, the metal content is much greater than that of the local soils, and even they are above the maximum concentrations recommended for agricultural soils (see values of CSTC in Table 2). It is possible to perceive that the mean variation ranges of As (232-992 mg kg ${ }^{-1}$ ), Cd (1.8-9.1 $\mathrm{mg} \mathrm{kg}^{-1}$ ) Cu 688-943 $\left.\mathrm{mg} \mathrm{kg}^{-1}\right)$, Pb (757-5156 mg kg ${ }^{-1}$ ) and $\mathrm{Zn}$ (851-3421 $\mathrm{mg} \mathrm{kg}^{-1}$ ) are significant higher showing clearly an increase in $\mathrm{C}_{\mathrm{f}}$ values. In the Algares area $\mathrm{As}$ e $\mathrm{Pb}$ are the elements which present the highest $\mathrm{C}_{f}$ values (Table 3 ) while in the $\mathrm{S}$. João do Deserto $\mathrm{Cd}$ and $\mathrm{Zn}$ represent the elements of concern (highest $\mathrm{C}_{\mathrm{f}}$ for both elements). Comparing the two areas, the Algares and S. João do Deserto, present a similar degree of contamination (see Table 3). These elements are delivered from tailings and minewaste tips to soils by wind, as dust particles, or by acid mine drainage in dissolved and particulate forms.

The mine waste materials in the Algares e São João do Deserto areas are undergoing reactions with air and rainwater. The exposure of pyrite-rich ore stockpiles and waste dumps to weathering processes led to the precipitation of white, green and yellow sulphate efflorescences and crusts. Sulphates include gypsum, halotrichite, melanterite type-phases, magnesiocopiapite, schwertmannite, and jarosite (Bobos et al, 2006). Many of these sulphates dissolve during rain events and subsequently re-form on drying periods. Also goethite and hematite occur in the substrate material. The dissolution of sulphide and the sulphate efflorescences led to production of $l o w \backslash p H$, metal rich-waters and the associated chemical and physical mobilization of heavy metals and metalloids to the local drainage system. According to Luis et al., (2009) surficial water samples of local streams, such as Água Azeda and Água Forte streams, affected by acid mine drainage (AMD) present low pH

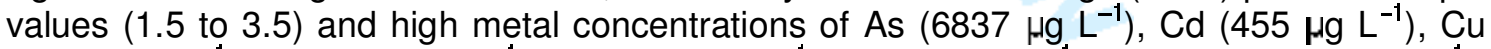

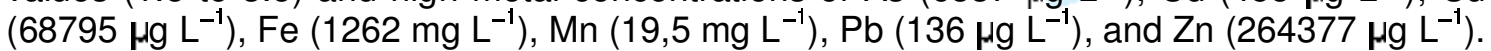
This acid and soluble acid mine generation could be controlled by covering and sealing sulphidic mine waste with local no contaminated soil or by the removal of the waste material by burying the material in the former main shaft. Collection and treatment of AMD could be achieved by a physical and chemical plant or construction of a wetland environment plus anoxic lime drains. Revegetation of disturbed areas should be considered using imported topsoil and local plant species.

\section{CONCLUSIONS}

The results of soil analysis from the mining area of Aljustrel (South of Portugal), show elevated concentrations of metals. The median concentrations particularly for $\mathrm{As}, \mathrm{Cd}, \mathrm{Cu}, \mathrm{Pb}$ and $\mathrm{Zn}$ are well above those of the regional baseline for world soils, the European Union and the Portugal and Andalusia. The same elements present concentrations that exceed the tentative guidelines set by Portugal and Andaluzia Guide Values. Parent rock lithology and 
597

mineralization seem to be the main factors influencing the abundance and distribution of trace elements. In some sites the concentrations of trace elements are significantly greater than the calculated threshold values. This may be ascribed to anthropogenic pollution, especially in Algares and S. João do Deserto areas where it is difficult to distinguish humaninduced pollution from natural mineralization.

The sequential extraction results showed that $\mathrm{As}, \mathrm{Cd}, \mathrm{Cu}, \mathrm{Pb}$ and $\mathrm{Zn}$ metals were mainly found in the sulphide/clay mineral fraction of the soil while $\mathrm{Co}, \mathrm{Cr}$ and $\mathrm{Ni}$ are mainly associated with the clay minerals and remaining silicates. Physical dispersion of sulphide minerals and also secondary metal-bearing minerals could be significant as revealed by the sequential extraction results. The chemical mobilization could also be pronounced for As, Cd, $\mathrm{Cu}, \mathrm{Pb}$ and $\mathrm{Zn}$ because the bioavailable fractions could be significant.

Rehabilitation of disturbed areas should involve covering and sealing sulphidic mine wastes or removal of mining waste material, installation of a physical and chemical plant or construction of a wetland environment (plus anoxic lime drains), and import of topsoil and planting of local, metal-tolerant plant species.

\section{ACKNOWLEDGEMENTS}

This study was carried out in the framework of the projects e-Ecorisk - A regional Enterprise Network Decision Support System for Environmental Risk and Disaster Management of Large-Scale Industrial Spills (contract n. EV41-CT- 2002-00068) and EVALUSE - Environmental Vulnerability of Aljustrel Mining Area in Terms of Land Use supported by the European Union and FCT - Fundação para a Ciência e Tecnologia, respectively.

\section{REFERENCES}

Abrahim GMS. Parker RJ., 2008. Assessment of Heavy Metal Enrichment Factors and the Degree of Contamination in Marine Sediments from Tamaki Estuary, Auckland, New Zealand. Environmental Monitoring Assessment, 136; 227-238.

Abrahim, GMS., 2005. Holocene Sediments of Tamaki Estuary: Characterisation and Impact of Recent Human Activity on an Urban Estuary in Auckland, New Zealand. Ph.D. thesis, University of Auckland, Auckland, New Zealand; 361.

Alloway BJ., 1995. Heavy metals in soils. Blackie Academic and Professional, London.

Alvarenga P., Palma P., Gonçalves AP., Fernandes RM., de Varennes A., Vallini G., Duarte E., Cunha-Queda AC., 2008. Evaluation of tests to assess the quality of mine-contaminated soil. Environmental Geochemistry and Health (2008) 30; 95-99

Andrade F., \& Schermerhorn L., 1971. Aljustrel e Gavião. Principais Jazigos Minerais do Sul de Portugal. Livro-Guia 4; 32-59.

Barriga FS., 1990. Metallogenesis in the Iberian Pyrite Belt. In: R.D. Dallmeyer and E. Martinez García, Editors, Pre-Mesozoic Geology of Iberia, Springer Verlag; 369-379.

Barriga FS., Carvalho D., Ribeiro A., 1997. Introduction to the Iberian Pyrite Belt; Society of Economic Geologists, Guidebook Series, v. 27; 1-20.

Barriga FS., Fyfe WS., 1988. Giant Pyritic basemetal deposits: the example of Feitais (Aljustrel, Portugal). Chemical Geology 69; 331-343.

Bobos I., Durães N., Noronha F., 2006. Mineralogy and geochemistry of mill tailings impoundments from Algares (Aljustrel), Portugal: Implications for acid sulfate mine waters formation. Journal of Geochemical Exploration 88; 1-5

Carvalho D., Barriga FJAS., Munhá J., 1999. Bimodal siliciclastic systems: the case of the Iberian Pyrite Belt, Reviews in Economic Geology 8; 375-408.

Cohen RRH and Gorman J., 1991. Mining-related nonpoint-source pollution. Water Environmental Technology; 55-9 
Davis JC. 1973. Statistics and data analysis in geology. John Wiley \& Sons, New York.

Dawson GL., Caessa P., Alverca R., Sousa JC., 2001. Geology of the Aljustrel Mine area, southern Portugal; GEODE Workshop "Massive sulfide deposits in the lberian Pyrite Belt: New advances and comparisons with equivalent systems", Aracena, Spain, October 2001: Aljustrel, Eurozinc, Aljustrel Field Trip Guidebook.

Domergue C., 1983. La mine antique d'Aljustrel (Portugal) et les tables de bronze de Vipasca. Conimbriga, XXII; 35.

Einax JW., Soldt U., 1999. Geostatistical and Multivariate Statistical Method for the Assessment of Polluted Soils; Merits and Limitations. Chemometrics Intell Lab; 79-91.

Evangelou VPB., Zhang YL. 1995. A review: Pyrite oxidation mechanisms and acid mine drainage prevention. Critical Reviews in Environmental Science Technology 25(2); 141-99

FAO, 1999. World Reference Base for Soil Resources (2 ${ }^{\text {nd }}$ ed.). World Soil Resources. Roma: Report 103.

Fernandes JC., Henriques FS., 1989. Holm-oak (quercus rotundifolia lam.) trees growing in a pyrites mining area at Aljustrel, Portugal. Water, Air, and Soil Pollution 48; 409-415.

Fernández-Caliani JC., Barba-Brioso C., González I., Galán E., 2009. Heavy Metal Pollution in Soils Around the Abandoned Mine Sites of the Iberian Pyrite Belt (Southwest Spain) Water Air Soil Pollution 200; 211-226.

Ferreira MMSI., 2004. Dados geoquímicos de base de solos de Portugal Continental, utilizando amostragem de baixa densidade. PhD Thesis, Universidade de Aveiro; 286pp.

Galán E., González I., Fernández-Caliani, 2002. Residual pollution load of soils impacted by the Aznacóllar (Spain) mining spill after clean-up operations. The Science on the Total Environment 286; 167-179.

Gibbs RJ., 1973. Mechanisms of trace metal transport in rivers. Science 180; 71-73.

Gómez-Ariza JI, Giradles I, Sánchez-Rodas D, Morales E. 2000. Metal sequential extraction procedure optimized for heavily polluted and iron oxide rich sediments. Analytical Chimica Acta 414; 151-164.

Goovaerts P., 1999. Using elevation to aid geostatistical mapping of rainfall erosivity. Catena 34; 227242.

Hakanson L., 1980. Ecological Risk Index for Aquatic Pollution Control, a Sedimentological Approach. Water Research, 14; 975-1001.

Junta de Andalucía, 2004. Estudio de Elementos Traza en Suelos de Andalucía. Consejería de Medio Ambiente. Junta de Andalucía. http://www.juntadeandalucia.es/medioambiente/site/web.

Kabata-Pendias A., H. Pendias, 2001. Trace Elements in Soil and Plants, 3rd Edn., Boca Raton, FL: CRC Press.

Kaiser HF., 1960. The Application of Electronic Computers to Factor Analysis. Edu. Psychol. Meas, 20; 141-151.

Kennedy VH., Sanchez AL., Oughton DH., Rowland AP., 1997. Use of single and sequential chemical extractants to assess radionuclide and heavy metals availability from soils to root uptake. Analyst, 122; 89R-100R.

Larocque ACL., Rasmussen PE., 1998. An overview of trace metals in the environment, from mobilization to remediation. Environmental Geology 33(2/3); 85-91

Leitão J., 1997. Geology of the Aljustrel massive sulfide deposits. Geology and VMS Deposits of the Iberian Pyrite Belt, Society of Economic Geologists Fieldbook Series 27; 82-97.

Levinson AA, 1980. An Introduction to Exploration Geochemistry. 2ne edn. Applied Publishing, Wilmette, Illinois.

Li X., Thornton I., 1993. Arsenic, antimony and bismuth in soil and pasture herbage in some old metalliferous mining areas in England. Environmental Geochemistry and Health 15; 135- 144. 
695

730

731

Lin YP., Teng TP. Chang TK., 2002. Multivariate Analysis of Soil Heavy Metal Pollution and Landscape Pattern in Changhua County in Taiwan. Landscape and Urban Planning, 62; 19-35.

Liu WH., Zhao JZ., Ouyang ZY., Solderland L., Liu GH., 2005. Impacts of Sewage Irrigation on Heavy Metal Distribution and Contamination in Beijing, China. Environ. Intl., 32; 805-812.

Luís AT., Teixeira P., Almeida SFP., Ector L., Matos JX., Ferreira da Silva EA., 2009. Impact of Acid Mine Drainage (AMD) on Water Quality, Stream Sediments and Periphytic Diatom Communities in the Surrounding Streams of Aljustrel Mining Area (Portugal). Water Air Soil Pollution 200; 147-167 DOI $10.1007 / \mathrm{s} 11270-008-9900-z$

Ma LQ, Rao GN. 1997 Chemical fractionation of cadmium, copper, nickel, and zinc in contaminated soils. Journal of Environmental Quality 26; 259-264.

Martins A., Alves H., Costa, T., 2003. 2000 anos de Mineração em Aljustrel; brochura da Exposição do Museu Municipal de Arqueologia de Aljustrel, Câmara Municipal de Aljustrel

Massart DL, Kaufman L, 1983. The Interpretation of Analytical Chemical Data by the Use of Cluster Analysis. New York: John Wiley \& Sons; 65.

Matos JX., 2005. Carta geológica e mineira da Mina de Aljustrel esc. 1/5000, INETI.

Matos JX., Martins LP., 2006. Reabilitação ambiental de áreas mineiras do sector português da Faixa Piritosa Ibérica: estado da arte e perspectivas futuras; Boletín Geológico y Minero, Espanha; 117 (2), 289-304.

Meguellati N, Robbe D, Marchandise P, Astruc M., 1983. A new chemical extraction procedure in the fractionation of heavy metals in sediments-interpretation. In Proceedings of the International Conference Heavy Metals in the Environment. CEP, Edinburgh; 1090-1093.

Merson J. 1992. Mining with microbes. New Science January; 9-17.

Millar S., 1995. Geochemical indicators of sulphide oxidation and acid generation in the field. In: Grundon N.J., Bell L.C.,(eds) Proceedings of the second Australian acid mine drainage workshop. Australian Centre for Minesite Rehabilitation Research, Brisbane; 117-120.

Oliveira JT., Relvas JMRS., Pereira Z., Matos JX., Rosa, CJ., Rosa D., et al., 2006. O Complexo Vulcano-Sedimentar da Faixa Piritosa: estratigrafia, vulcanismo, mineralizações associadas e evolução tectonoestratigráfica no contexto da Zona Sul Portugesa. In R. Dias, A. Araújo, P. Terrinha, \& J.C. Kulberg (Eds.), Geologia de Portugal no Contexto da Ibéria (pp. 207-244). Univ. Évora, Portugal: VII Cong. Nac. Geologia.

Pacheco N., Caravalho P., Ferreira A., 1998. Geologia da Mina de Neves Corco e do Vulcanismo do Anticlinório de Panóias - Castro Verde; V Congresso nacional de Geologia, Livro-Guia de Excursões

Patinha C., Correia E., Ferreira da Silva E., Simões A., Reis, P., Morgado F., Cardodo Fonseca E., 2008. Definition of geochemical patterns on the soil of Paul de Arzila using correspondnce analysis. Journal of Geochemical Exploration 98; 34-42.

Pereira R., Ribeiro R., Gonçalves F., 2004. Plan for an Integrated Human and Environmental Risk Assessment in the S. Domingos Mine Area (Portugal). Human and Ecological Risk Assessment: An International Journal 10, 3; 543-578.

Perona E., Bonilla I., Mateo P., 1999. Spatial and temporal changes in water quality in a Spanish river. The Science of the Total Environment, 241; 75-90. doi:10.1016/S0048-9697(99)00334-4

Pickering WF, 1986. Metal ion speciation - soils and sediment. Ore Geol. Rev 1; 83-146.

Pierzynski GM., Vance GF., Sims JT., 1994. Soils and Environmental Quality. Boca Raton : CRC Press.

Qishlaqi, F. Moore, 2007. Statistical analysis of Accumulation and Sources of Heavy Metals Occurrence in Agricultural Soils of Khoshk River Banks, Shiraz, Iran. American-Eurasian J. Agric. Environ. Sci. 2 (5); 565-573.

Quevauviller P., Rauret G., Muntuau H, Ure A., Rubio R., López-Sánchez JF., Fielder HD., Griepink B. 1994. Evaluation of sequential extraction procedure for the determination of extractable trace metal contents in sediments. Fresenius Journal of Analytical Chemistry 349; 808-814. 
744

Rapin F, Forstner U., 1983. Sequential leaching techniques for particulate metal speciation: the selectivity of various extractants. In Proceedings of the 4th International Conference on Heavy Metals in the Environment, 2. Heidelberg. Germany; 1074-1077.

Rasmussen PE., 1998. Long-range atmospheric transport of trace metals: The need for geosciences perspectives. Environmental Geology 33 (3/2); 96-108

Reimann C., De Caritat P., 1998. Chemical elements in the environment. Berlin: Springer.

Reis AP., Ferreira da Silva E., Matos J., Patinha C., Sousa AJ. e Cardoso Fonseca E., 2005. Combining GIS and stochastic simulation to define spatial patterns of variability for lead at the Lousal mine, Portugal. Land Degradation and Development, Wiley Europe; 229-242.

Reis AP., Sousa AJ., Ferreira da Silva E., Patinha C., Cardoso Fonseca E., 2004. Combining multiple correspondence analysis with factorial kriging analysis for geochemical mapping of the gold-silver deposit at Marrancos (Portugal). Applied Geochemistry 19(4);623-631

Relvas, JS., 2006. Hydrothermal Alteration and Mineralization in the Neves-Corvo Volcanic-Hosted Massive Sulfide Deposit, Portugal; I. Geology, Mineralogy, and Geochemistry. Economic Geology

Relvas JS., Massano C., Barriga F., 1990. Ore zone hydrothermal alteration around the Gavião orebodies: implications for exploration in the Iberian Pyrite Belt. Actas da VIII Semana de Geoquímica, Lisboa.

Salman SR., YH. Abu Rukah, 1999. Multivariate and Principal Component Statistical Analysis of Contamination in Urban and Agricultural Soils from North Jordan. Environmental Geology; 38, 256270.

Salminen R., Tarvainen T., 1997. The problem of defining geochemical baselines. A case study of selected elements and geological materials in Finland. Journal of Geochemical Exploration 60; 91-98.

Santos Oliveira JM., Farinha J., Matos JX., Ávila P., Rosa C., Canto Machado MJ., Daniel FS., Martins L., Machado Leite MR., 2002. Diagnóstico Ambiental das Principais Áreas Mineiras Degradadas do País. Boletim de Minas 39 (2); 67-85.

Schermerhorn L., Zbyzewski G., Ferreira, V. 1987. Not. Exp. Carta Geológica Portugal FI. 42D, SGP, $55 \mathrm{pp}$.

Schermerhorn L., Andrade R.,1971. A Faixa Piritosa do Sul de Portugal; I Congresso HispanoAmericano de Geologia Económica; Livro-guia da Excursão, n. ${ }^{4}$ - Principais Jazigos Minerais do Sul de Portugal.

Schermerhorn LJG., Stanton WL.,1987. Notícia explicativa da Carta Geológica de Portugal, folha 42D Aljustrel, 1/50000; Serviços Geológicos de Portugal; p55

Silva JB., Oliveira V., Matos J., Leitão, JC., 1997. Field Trip nำ, Aljustrel and Central Iberian Pyrite Belt. SEG Neves Corvo Field Conference. Guidebook series, 27; 73-124.

Sims JT., Cunningham SA., Summer ME., 1997. Assessing soil quality for environmental purposes : roles and challenges for soil scientists. Journal Environmental Quality 26 ; 20-25

Soucek DJ., Cherry DS., Currie RJ., 2000. Laboratory to field validation in an integrative assessment of an acid mine drainage-impacted watershed. Environ Toxicol and Chem 19 (4); 1036-1043.

Strauss GK., Madel J., 1974. Geology of massive sulphide deposits in the Spanish Portuguese Pyrite Belt. Geologische Rundschau, 63; 191-211.

Tessier A., Campbell PGC., Bisson M., 1979. Sequential extraction procedure for the speciation of particulate trace metals. Analytical Chemistry, 51 (7); 844-851.

Thornton I., 1996. Impacts of mining on the environment: some local, regional and global issues. Applied Geochemistry, 11; 355-361.

Tornos F., 2006. Environment of formation and styles of volcanogenic massive sulfides: the Iberian Pyrite Belt. Ore Geology Reviews, 28; 259-307. doi:10.1016/j.oregeorev. 2004.12.005.

Tuncer GT., Tuncel SG., Tuncel G., Balkas TI., 1993. Metal Pollution in the Golden Horn, TurkeyContribution of Natural and Anthropogenic Components since 1913. Water Science Technology, 28; 50-64. 
793 Wackernagel H., 1998. Multivariate geostatistics, An introduction with applications. 2nd ed. Springer 794 Verlag, Berlin.

795 Webster R., Oliver MA., 1990. Statistical methods in soil and land resource survey. Oxford Univ. 796 Press, Oxford.

797 Yan X-P, Kerrich R., Hendry MJ., 1999. Sequential leachates of multiple grain size fractions from a 798 clay-rich till, Sakatchewan, Canada: implications for control on the rare earth element geochemistry of 799 pore waters in an aquitard. Chemical Geology 158, 53-79.

800 Yukselen MA., Alpaslan B., 2001. Leaching of metals from soil contaminated by mining activities. 801 Journal Hazard Materials B87; 289-300

802 Zhou QX., Kong FX., Zhu L., 2004 Ecotoxicology, Beijing, China: Science Press(in Chinese).

803 Zhou QX., Sun TH., 2002. Effects of chromium (VI) on extractability and plant uptake of fluorine 804 agricultural soils of Zhejiang Province, China. Water Air Soil Pollution 133; 145-160. 


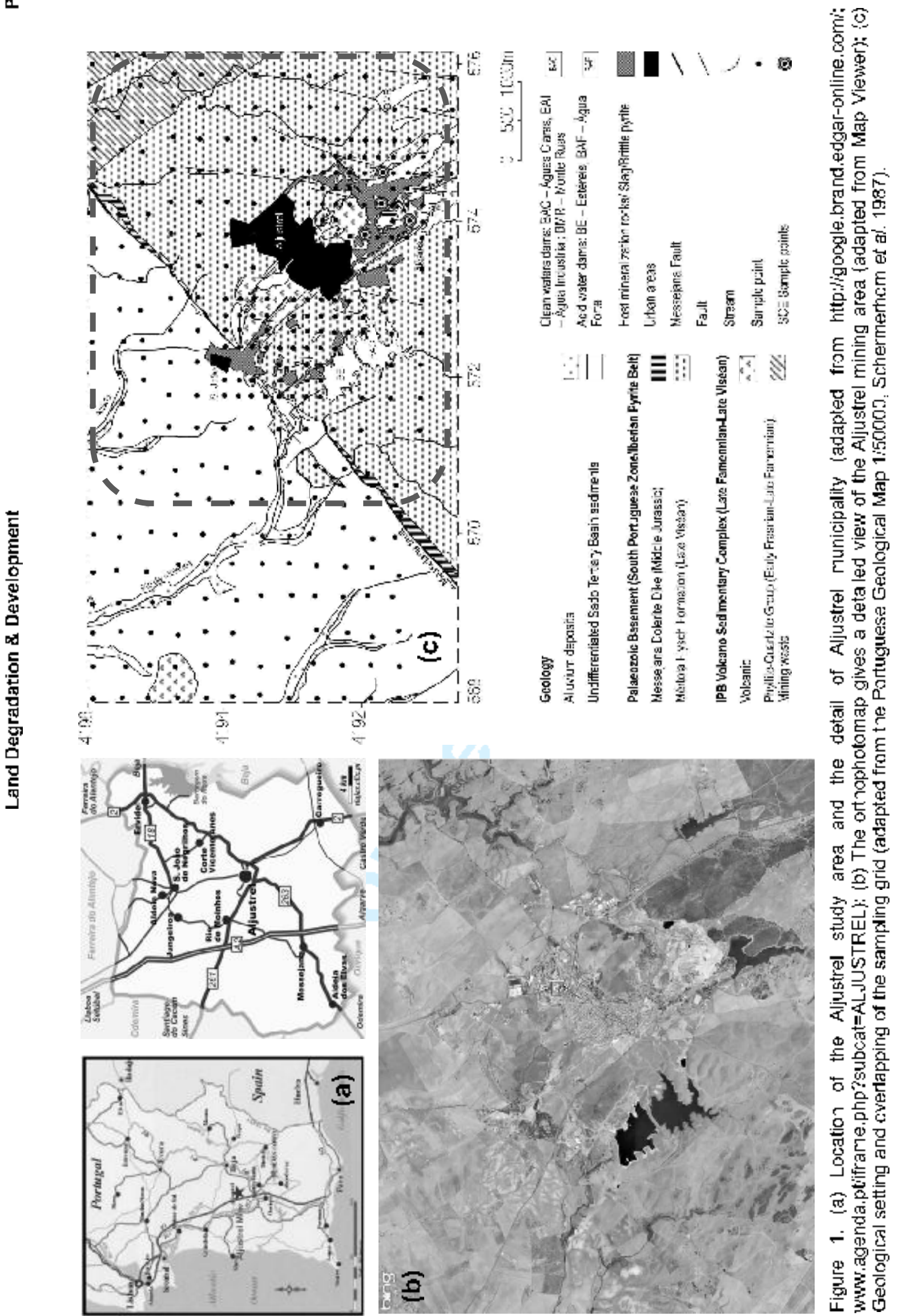




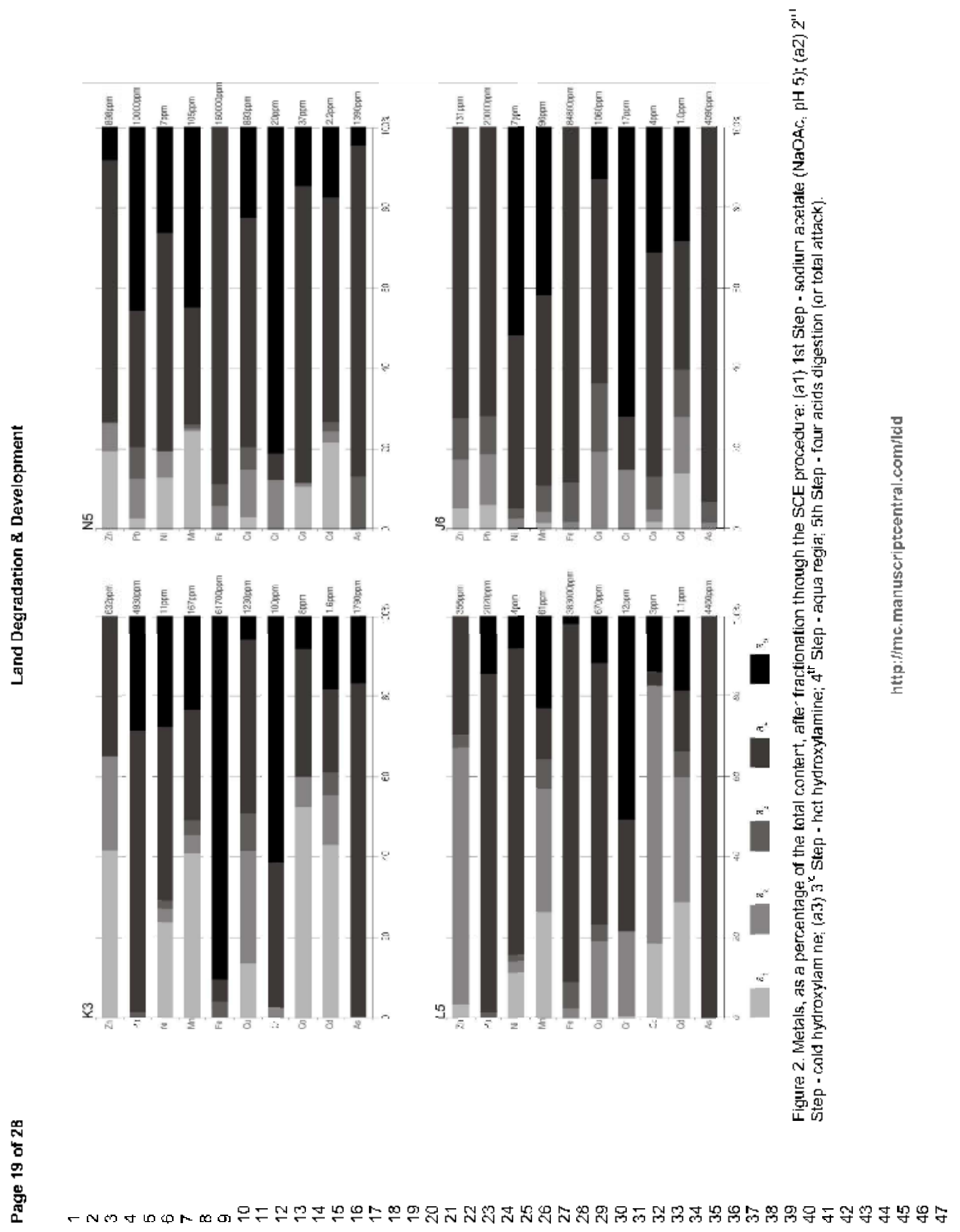




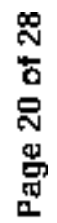

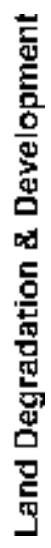

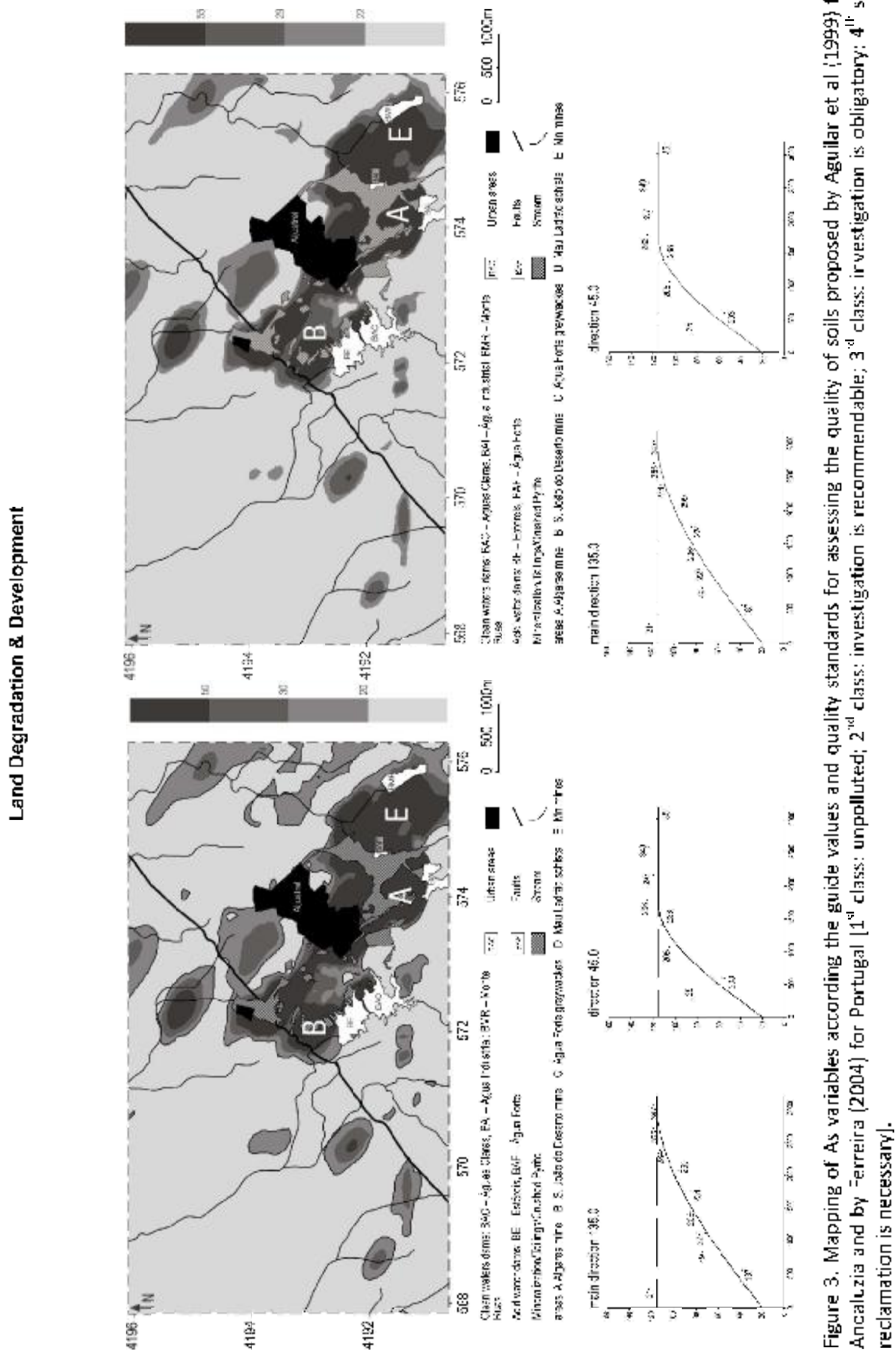

点 


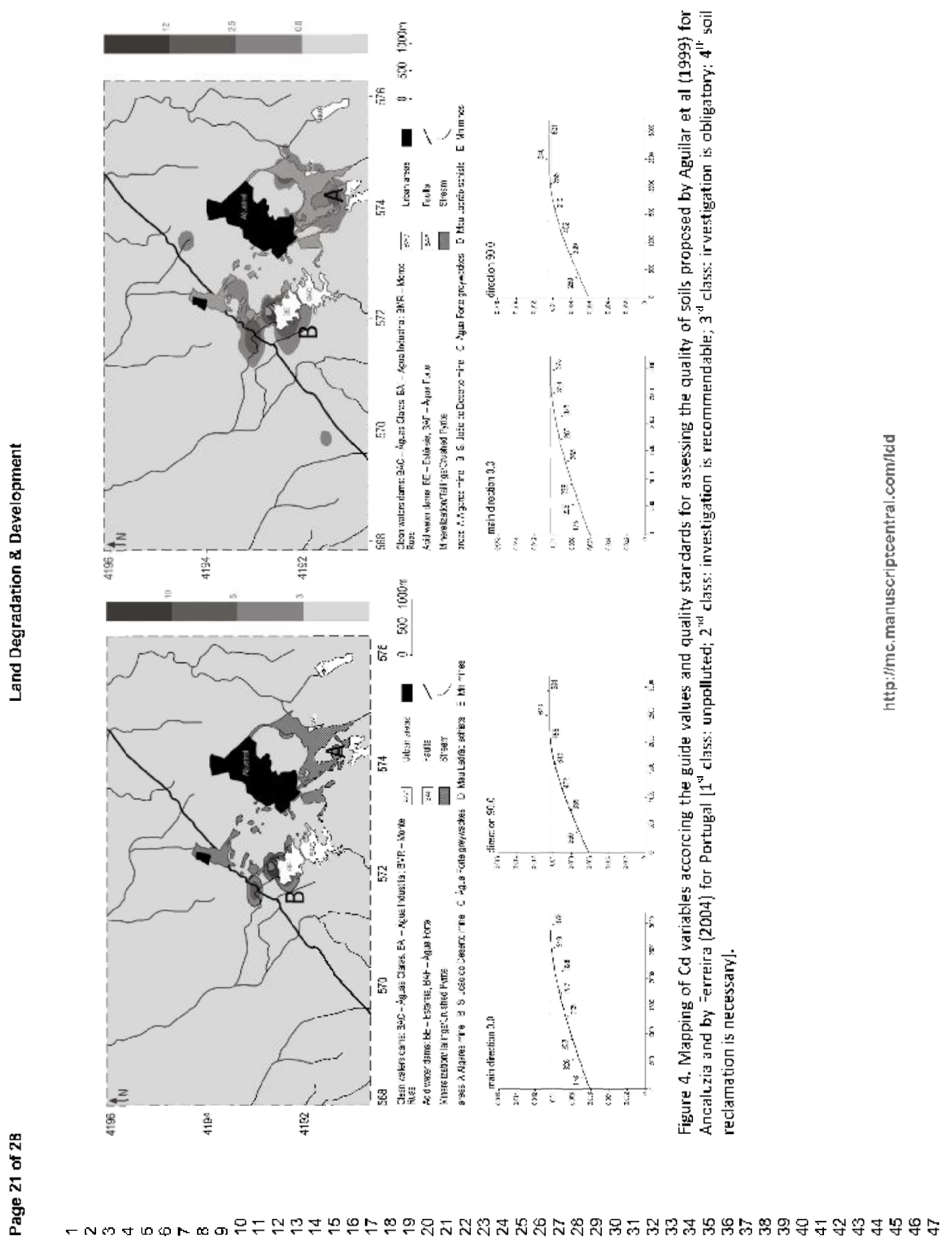




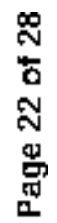

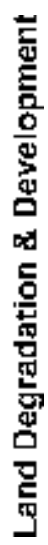

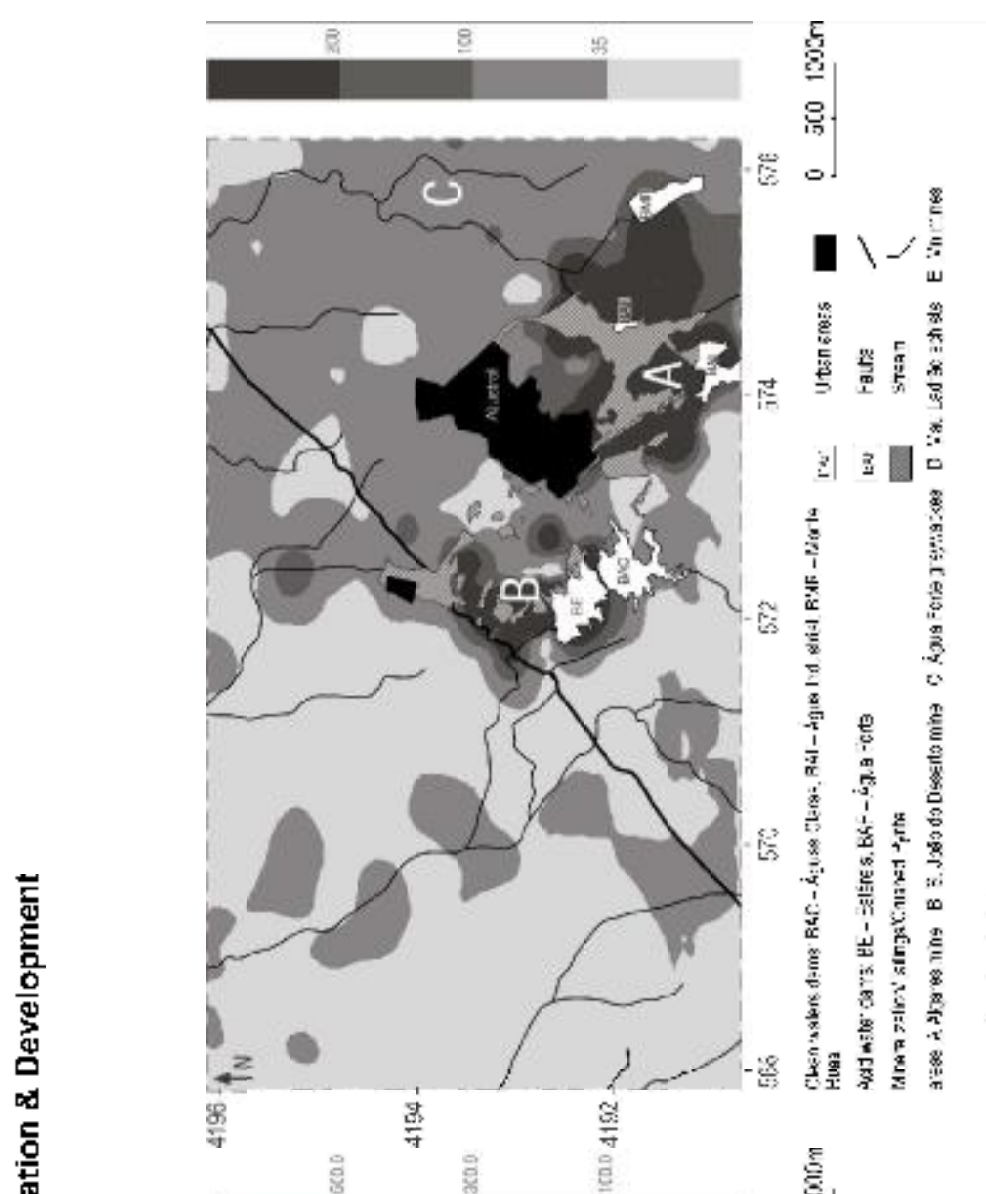

窇.

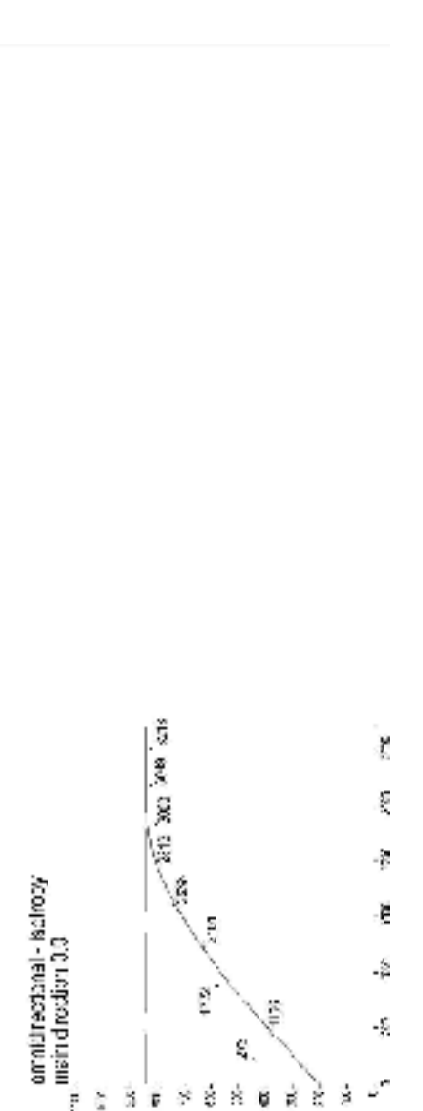

का

䨔

古菒

蒠

恶

호

要

豆

施

는 $\frac{n}{0}$

岩

妾

可 듬

省

鈭

竞

吕 들

可

证

몽

焉

吾

굴

㤐竞

焉

前染

梠

包

可

를

8

点

些

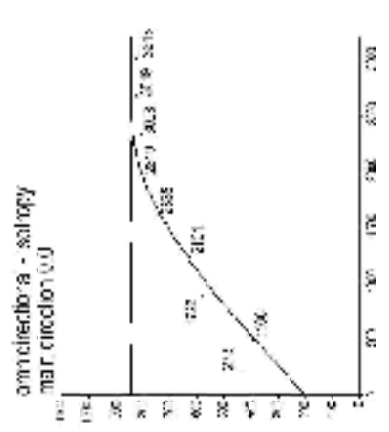

宽

$\mathrm{g}$

需要

메

言豆

들

要

का

픈 $\frac{}{\mathrm{N}}$

列它要 


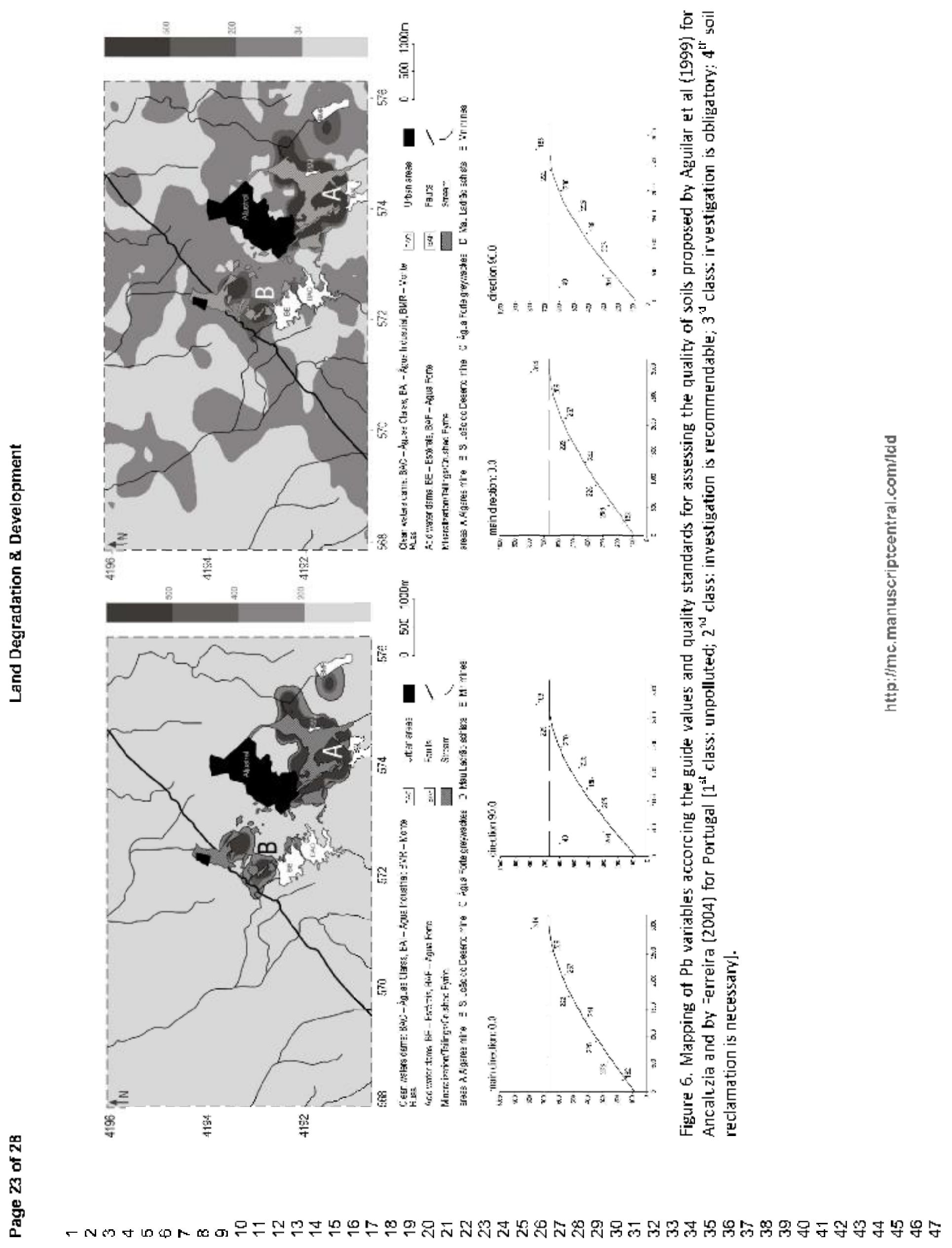




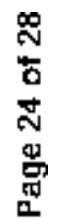

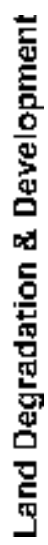

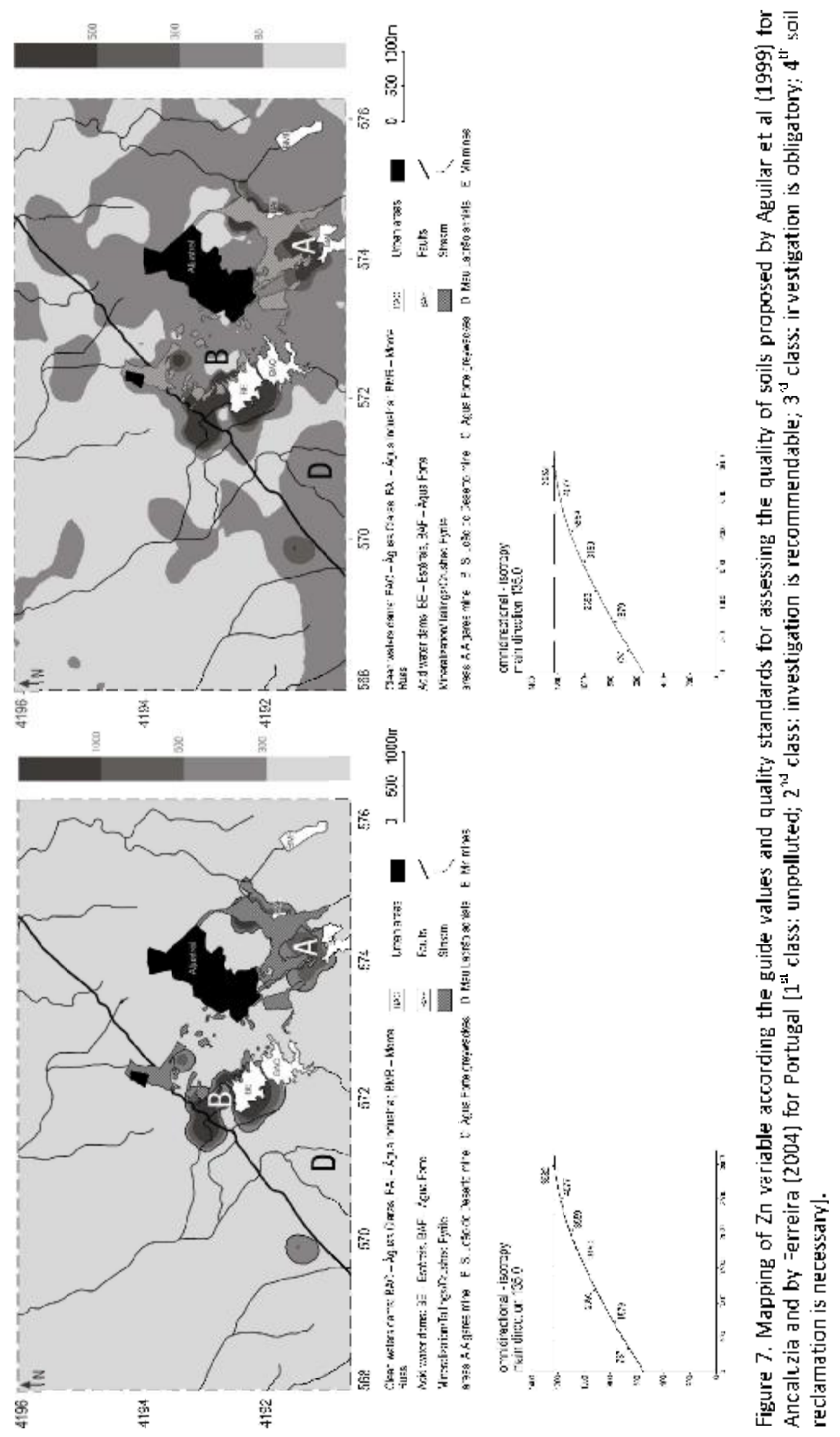




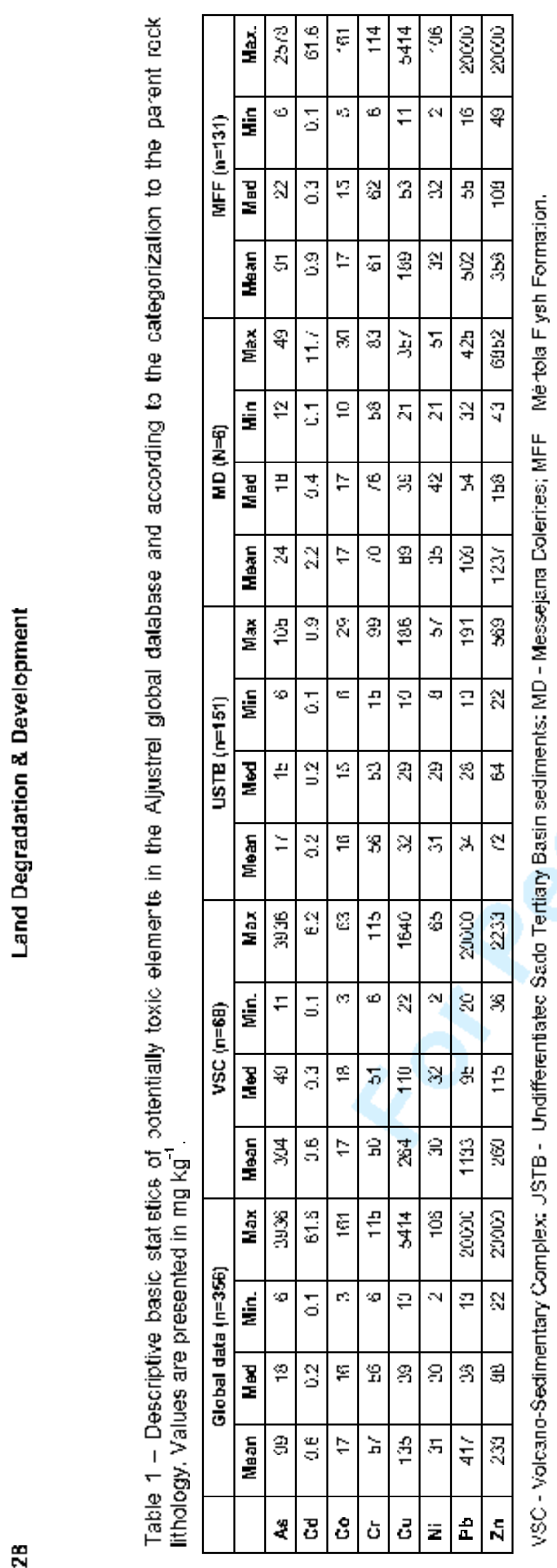




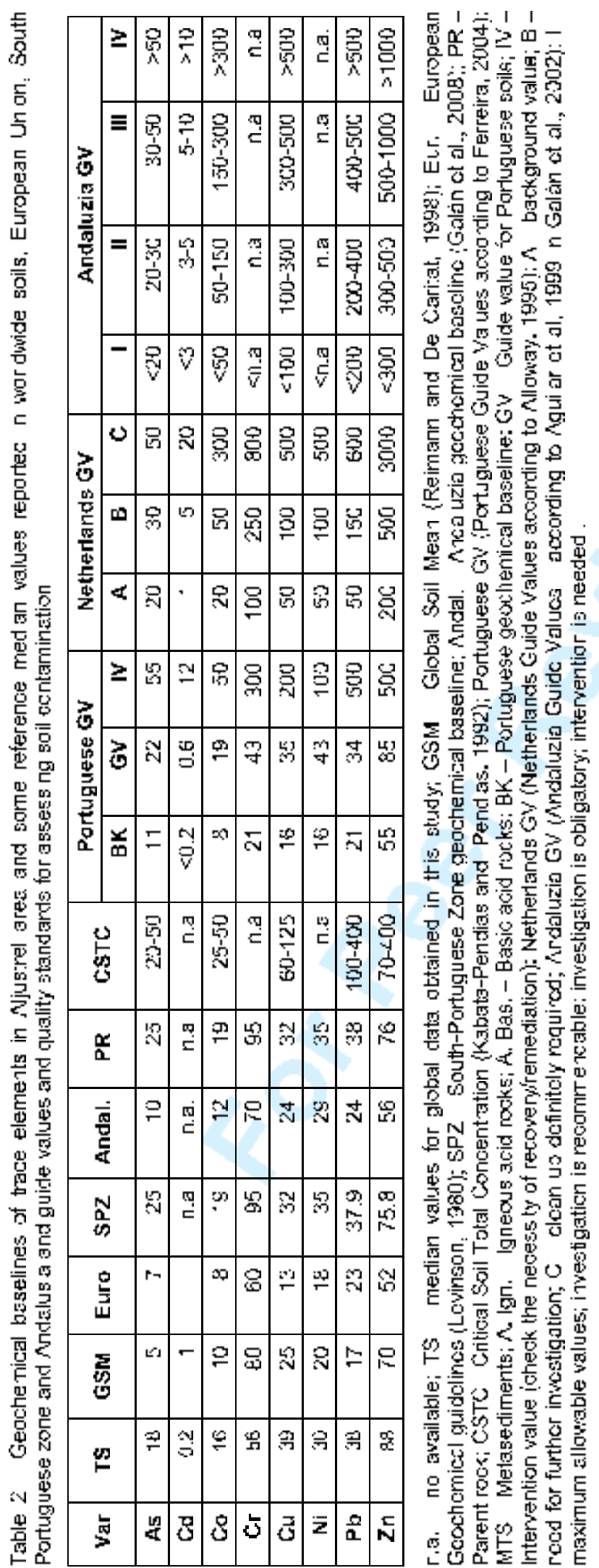


Table 3 - Contamination factors $\left(\mathrm{C}_{\mathrm{f}}\right)$ and modified degree of contamination $\left(\mathrm{mC}_{\mathrm{f}}\right)$ using baseline values (median value for global data) and median values for heavy metals in each parent rock lithology

\begin{tabular}{|c|c|c|c|c|c|c|c|c|c|}
\hline & As & $\mathrm{Cd}$ & $\mathrm{Ca}$ & $\mathrm{Cr}$ & $\mathrm{Cu}$ & $\mathrm{Ni}$ & $\mathrm{Pb}$ & In & $m c_{r}$ \\
\hline 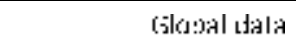 & 5,50 & 3,00 & 1,06 & 1,02 & 3,46 & 1.09 & 10.97 & 2,65 & 3,59 \\
\hline $\mathrm{VSC}$ & 6,20 & 2,00 & 9,94 & 9,98 & 2,40 & 9,94 & 11.93 & 2,26 & 3,46 \\
\hline U.STE & $L, 13$ & 1,00 & 1,07 & 1.05 & 1.10 & 1.07 & 1,21 & 1,13 & 1.10 \\
\hline आए & 1,33 & 5,50 & 1,00 & 0,92 & 2,29 & 0,93 & 2,02 & 7,83 & 2,71 \\
\hline МГГ & $4,1+$ & 3,00 & 1,13 & 0,99 & 3,57 & 1,00 & 9,13 & 3,31 & 3,29 \\
\hline M gares area & 20.2 & 5.9 & 1.1 & $\pi .5$ & 8.5 & $\pi .5$ & 54.2 & 7.4 & 12.3 \\
\hline ร. I | & 4.7 & $3 n .2$ & 2.0 & I.1 & h. .3 & 1.3 & 8.0 & 29.8 & 18.4 \\
\hline
\end{tabular}


Table 4 - Sample distribution between the different classes taking in consideration the Portuguese and Andaluzian Guide Values [1:1 clas5: unpolluted; $2^{\text {ril }}$ class: irvestigation is recommendable; $3^{\text {r: }}$ class: investigation is obligatory: $4^{\text {th }}$ soil reclamation is necessary].

\begin{tabular}{rrrrrrrrr}
\hline \multicolumn{4}{c}{ Portugal Guide U'alues } \\
\hline & Class 1 & Class 2 & Class 3 & Class 4 & Class 1 & Class 2 & Class 3 & Class 4 \\
\hline As & $40(11.2 \%)$ & $194(54.5 \%)$ & $64(18 \%)$ & $58(16.2 \%)$ & $213(59,8 \%)$ & $55(15,4 \%)$ & $28(7,9 \%)$ & $61(17,1 \%)$ \\
Cu & $207(58.1)$ & $117(32.9 \%)$ & $30(8.4 \%)$ & $2(0.6 \%)$ & $352(98,9 \%)$ & $0(0,0 \%)$ & $1(0,3 \%)$ & $3(0,8 \%)$ \\
Cu & $10(2.8 \%)$ & $137(38.5 \%)$ & $166(46.6 \%)$ & $43(12.1 \%)$ & $281(78,9 \%)$ & $40(11,2 \%)$ & $16(4,5 \%)$ & $19(5,3 \%)$ \\
Pb & $40(11.2 \%)$ & $246(69.1 \%)$ & $69(19.4 \%)$ & $1(0.3 \%)$ & $317(89,0 \%)$ & $10(2,8 \%)$ & $5(1,4 \%)$ & $24(6,7 \%)$ \\
乙n & $63(17.7 \%)$ & $110(30.9 \%)$ & $166(46.6 \%)$ & $17(4.8 \%)$ & $330(92,7 \%)$ & $9(2,5 \%)$ & $11(3,1 \%)$ & $6(1,7 \%)$ \\
\hline
\end{tabular}

